\title{
Rapid Analysis of
}

\section{Silicate Rocks}

GEOLOGICAL SURVEY BULLETIN 1036-C

Revised from Circular 165
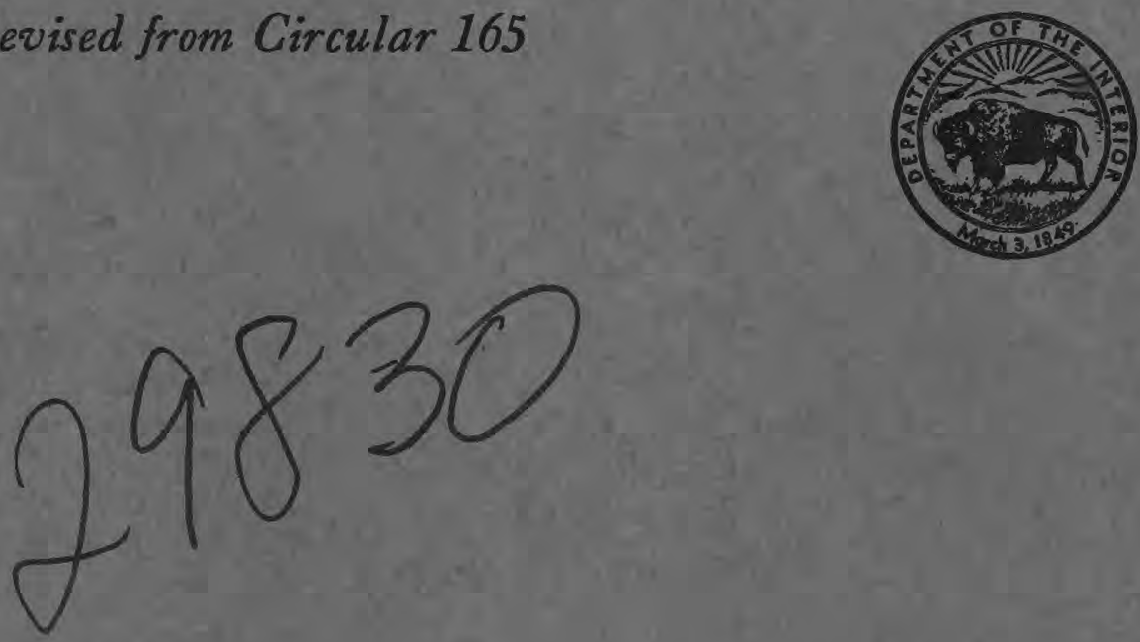


\section{Rapid Analysis of}

\section{Silicate Rocks}

By LEONARD SHAPIRO and $\mathrm{W}$. W. BRANNOCK

A CONTRIBUTION TO GEOCHEMISTRY

GE OL O I CAL S UR VEY B ULLE T I N 1036-C

Revised from Circular 165 


\title{
UNITED STATES DEPARTMENT OF THE INTERIOR
}

Douglas McKay, Secretary

\author{
GEOLOGIGAL SURVEY
}

W. E. Wrather, Director

For sale by the Superintendent of Documents, U. S. Government Printing Office Washington 25, D. C. - Price 20 cents (paper cover) 


\section{CONTENTS}

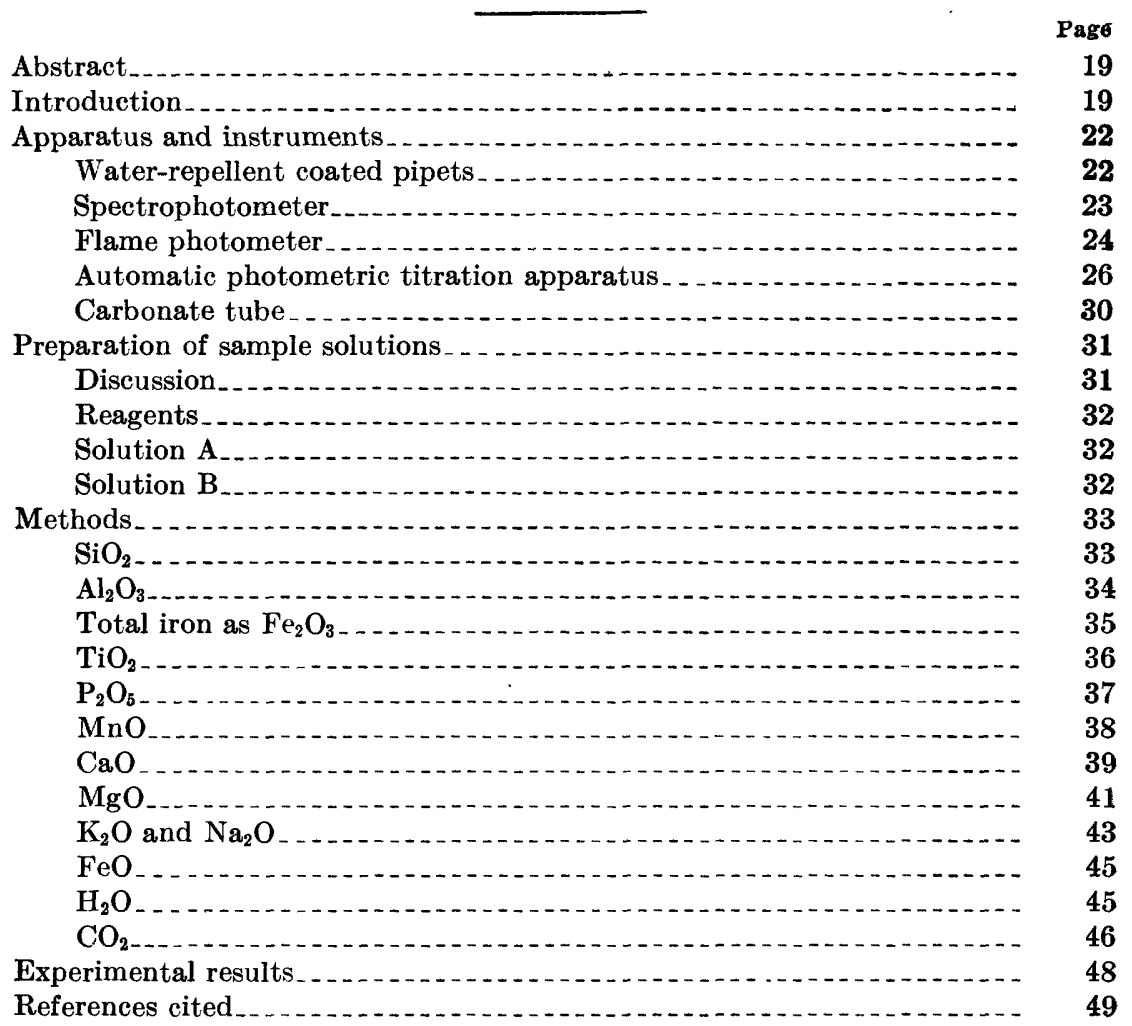

\section{ILLUSTRATIONS}

FIGURE 4. Flow diagram for rapid analysis of silicate rocks

5. Cell and cell adapter for the spectrophotometer.

6. Special glass atomizer for the flame photometer

7. Titration assembly

8. Titrator-front removed

9. Circuitry of titrator

10. Carbonate tube ........ 31

11. Titration curve

12. Water tube being heated on a support $\ldots \ldots \ldots 7$ 


\section{TABLES}

TABLE 1. Conversion of percent transmission (T) to absorbance (A) _._.

2. Concentration ranges of test samples . . . . . .

3. Results obtained for National Bureau of Standards mixture

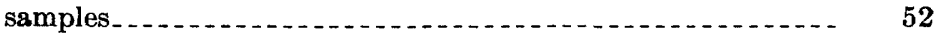

4. Results obtained for two National Bureau of Standards standard

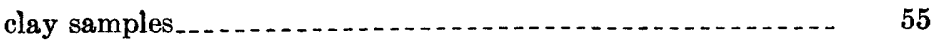

5. Comparison of results obtained by rapid and conventional analysis of two carefully studied rock samples............. 


\title{
A CONTRIBUTION TO GEOCHEMISTRY
}

\author{
RAPID ANALYSIS OF SILICATE ROGKS
}

\author{
By Leonard Shapiro and W. W. Brannock
}

\begin{abstract}
Rapid methods are described for the determination of the major constituents in silicate rocks. Silica and alumina are determined spectrophotometrically on aliquots of a solution prepared by fusion of the sample with $\mathrm{NaOH}$; a molybdenum blue method is used for $\mathrm{SiO}_{2}$; and alizarin red-S is used in the determination of $\mathrm{Al}_{2} \mathrm{O}_{3}$. A second solution prepared by digestion of the sample with $\mathrm{HF}$ and $\mathrm{H}_{2} \mathrm{SO}_{4}$ is used for the determination of $\mathrm{TiO}_{2}$, total iron, $\mathrm{MnO}$, and $\mathrm{P}_{2} \mathrm{O}_{5}$, by spectrophotometric methods. $\mathrm{TiO}_{2}$ is determined with tiron, total iron with orthophenanthroline, $\mathrm{MnO}$ as the permanganate, and $\mathrm{P}_{2} \mathrm{O}_{5}$ as molybdivanadophosphorie acid. Additional aliquots of the second solution are taken to determine $\mathrm{CaO}$ and $\mathrm{MgO}$ with an automatic photometric titrator using Versene (disodium ethylenediamine tetraacetate), the $\mathrm{CaO}$ being first precipitated before titrating the $\mathrm{MgO}$. Another aliquot of the same solution is used for the determination of $\mathrm{K}_{2} \mathrm{O}$ and $\mathrm{Na}_{2} \mathrm{O}$ by flame photometer. $\mathrm{FeO}$ is determined by titration with $\mathrm{K}_{2} \mathrm{Cr}_{2} \mathrm{O}_{7}$ after decomposition of a separate portion of sample with $\mathrm{HF}$ and $\mathrm{H}_{2} \mathrm{SO}_{4}$. Total $\mathrm{H}_{2} \mathrm{O}$ is determined by a modified Penfield method, and $\mathrm{CO}_{2}$ is determined by measuring the volume of gas released by boiling a portion of sample powder with acid. Results of rapid analysis of twelve synthetic mixtures, two National Bureau of Standards standard samples, and two carefully studied silicate rocks are compared with the reported values.
\end{abstract}

\section{INTRODUCTION}

The greatly expanded program of the Geological Survey, following World War II, was accompanied by a greatly increased need for chemical analysis of rocks and other geological materials. At that time sufficient personnel and laboratory facilities were not available, or practicably obtainable to keep pace with the growing need.

The classical methods of rock analysis, essentially unchanged since they were described by Hillebrand (1900) are by their nature slow and complicated. They cannot readily be adapted for rapid analysis of large numbers of samples, and they must be used by highly skilled analysts.

For many geological problems approximate analyses are suitable. Accordingly a program of research was begun in 1950 aimed at the development of economical methods for making approximate analyses. 
The first satisfactory scheme developed was for the rapid analysis of silicate rocks. It is described in U. S. Geological Survey Circular 165 (Shapiro and Brannock, 1952).

Application of the procedures in day to day analysis of a large number of rock samples indicated that it might be possible to improve and expand the methods of the original scheme of analysis so that by duplicate analyses results could be obtained at a rapid rate, which would be as accurate as those usually reported for analyses by classical methods. The procedures have been improved and expanded by refinement of the original ones as well as by substitution and addition of new ones. The present state of these methods for silicate rocks is described in this bulletin. The scheme described here provides for the determination of $\mathrm{SiO}_{2}, \mathrm{Al}_{2} \mathrm{O}_{3}, \mathrm{Fe}_{2} \mathrm{O}_{3}, \mathrm{FeO}, \mathrm{MgO}, \mathrm{CaO}, \mathrm{Na}_{2} \mathrm{O}$, $\mathrm{K}_{2} \mathrm{O}$, $\mathrm{TiO}_{2}, \mathrm{P}_{2} \mathrm{O}_{5}, \mathrm{MnO}, \mathrm{H}_{2} \mathrm{O}$, and $\mathrm{CO}_{2}$, the constituents commonly determined in silicate rocks. From 1951 to March 1955, 952 samples of silicate rocks have been analyzed by these rapid procedures. In addition, the procedures have been modified in various ways for the analysis of 871 samples of nonsilicate rocks in the same period.

The methods are rapid, simple, direct, and are less subjective than conventional methods. They can be easily learned and carried out by analysts with considerably less training than that required for analysis by classical methods. The rate of production for complete analyses can be as much as 7 times that of the conventional methods or, if done in duplicate, results of comparable accuracy can be obtained at a rate of 2 to 3 times that of the conventional methods.

There are several inherent advantages. The determination of all of the constituents except two are direct and are not based on quantitative separations or corrections. For example when $\mathrm{MgO}$ is determined an aliquot is taken from a stock solution of the sample and just this single constituent is run. In contrast, when conventional procedures are used, a long series of careful separations must be made. The two cases in which there remains some dependence on other determinations are ferric oxide and alumina. The $\mathrm{Fe}_{2} \mathrm{O}_{3}$ result is based on the difference between total iron and $\mathrm{FeO}$ as it is in the conventional methods. The $\mathrm{Al}_{2} \mathrm{O}_{3}$ value requires only a small correction based on the $\mathrm{TiO}_{2}$ concentration in the sample.

$\mathrm{By}$ virtue of the independence of the individual determinations a summation of the results by rapid analysis has more significance than a summation in conventional procedures. With conventional procedures a constituent may be incompletely precipitated at one stage and subsequently precipitated with another constituent and yet provide a good summation.

The methods described, with appropriate modifications, have been used in the analysis of numerous samples of diverse materials such as 
salines, waters, iron ores, bauxites, chromites, alunites, and carbonate rocks.

For the sake of simplicity, the procedures for the preparation of sample solutions and for the various determinations describe the analysis of a single sample. Large numbers of samples can be most efficiently analyzed in batches of ten to twenty samples at a time.

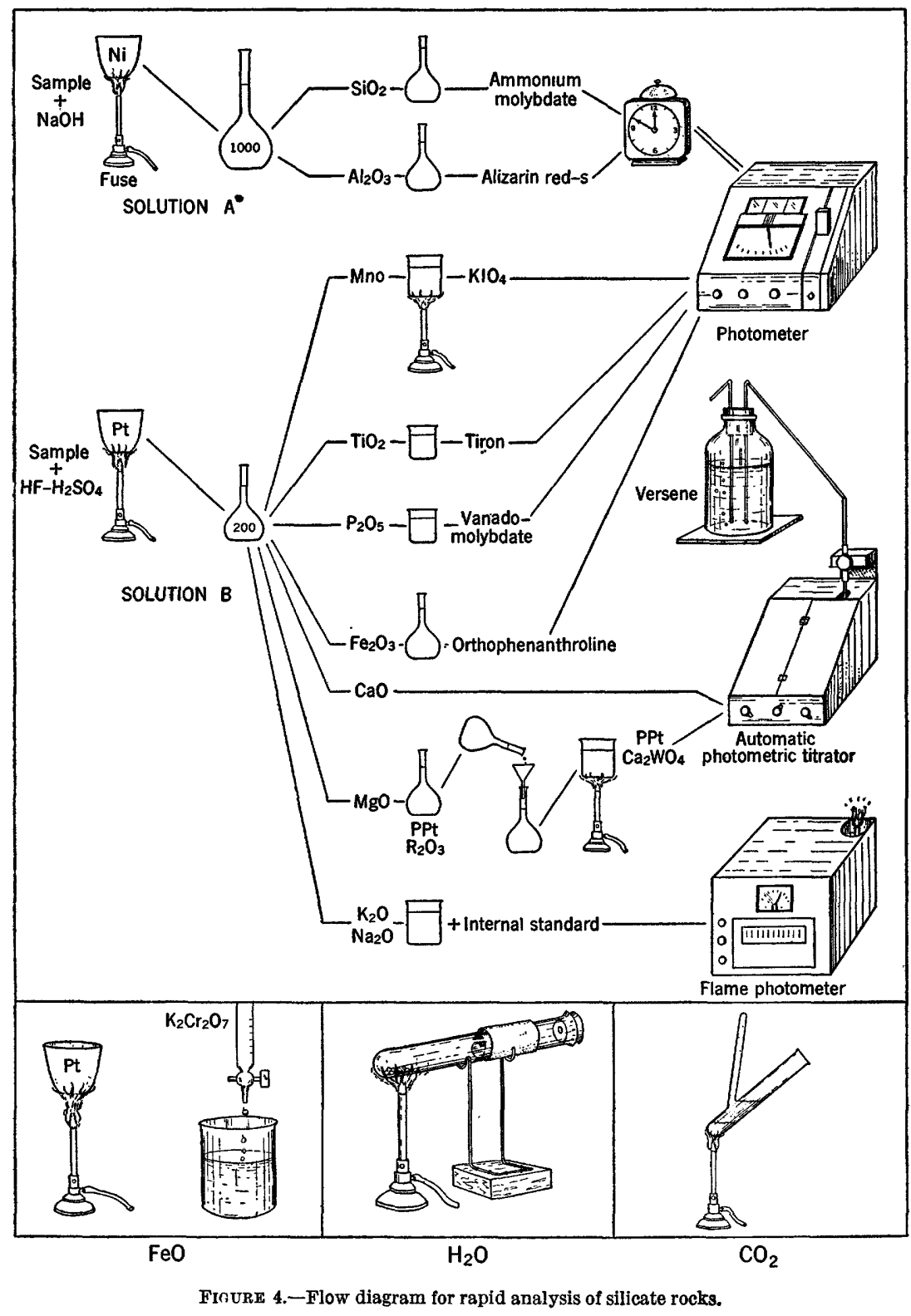


The actual number of samples per batch should be based on the amount of apparatus available. Unless specific instruction to the contrary is given, the operation described for each step in a procedure should be completed for all the samples in a batch before proceeding with subsequent steps.

\section{APPARATUS AND INSTRUMENTS}

Most of the apparatus used in the procedures described is available in laboratories making silicate rock analyses. In addition to commonplace items such as beakers, volumetric flasks, Pyrex bottles, burets, pipets, funnels, analytical balance, and filter paper, several more specialized types of apparatus are needed. They are a spectrophotometer, a flame photometer, an automatic photometric titrator, and a carbonate tube.

In the preparation of solutions for determination of $\mathrm{SiO}_{2}$ and $\mathrm{Al}_{2} \mathrm{O}_{3}$, the samples are fused in covered nickel crucibles of approximately 75-ml capacity.

Platinum crucibles of about $100 \mathrm{ml}$, with covers, are used in the preparation of the solution (solution $\mathrm{B}$ ) from which aliquots are taken for the determination of total iron, $\mathrm{TiO}_{2}, \mathrm{P}_{2} \mathrm{O}_{5}, \mathrm{MnO}, \mathrm{CaO}, \mathrm{MgO}$, $\mathrm{K}_{2} \mathrm{O}$, and $\mathrm{Na}_{2} \mathrm{O}$. These crucibles are also used in the determination of $\mathrm{FeO}$.

\section{WATER-REPELLANT COATED PIPETS}

The use of water-repellent coated pipets makes possible a substantial saving of time. Rinsing between samples is eliminated as coated pipets retain only negligible quantities of liquid. With a coated pipet, aliquots from 20 samples (without intermediate rinsing) are made easily in 5 minutes. The precision is at least as good as for conventional pipets, but as the accuracy may be slightly off it is necessary to pipet both the samples and the standard with the same pipet, or to use pipets known to deliver essentially equal volumes of solution.

Delivery time can be as little as 6 to 10 seconds without loss of accuracy. Pipets for all uses except those involving strongly alkaline solutions should be treated as follows: Cut approximately $3 / 16$ in. from the tip of a regular transfer pipet and carefully fire-polish the cut edge slightly to round the edges. Allow the pipet to cool and check the delivery time which should be between 6 and 10 seconds, regardless of pipet capacity. If necessary, fire-polish a little more, or dip the tip into HF solution for a few minutes depending on whether the delivery time is more than 10 seconds or less than 6 seconds. Recheck and repeat until within this range. Clean the pipets thoroughly in cleaning solution and rinse well with water. Allow to dry thoroughly. 
Coat the pipet with water-repellent according to the directions of the manufacturer. Dimethyl dichlorosilane is very convenient to use as it is necessary only to flow it in and out of the clean pipet, then allowed to dry.

\section{SPECTROPHOTOMETER}

All spectrophotometric measurements were made with a Beckman model B spectrophotometer. Nevertheless, the methods can readily be adapted to use other good quality spectrophotometers. Only one phototube was employed for the measurements, all of which were made in the range $320-700 \mathrm{~m} \mu$.

To insure the stability of the source of illumination a storage battery was used. The amplifier circuit of the instrument was fed by an a-c line. In place of a set of large matched test tubes previously used as absorption tubes, a single fixed tube with a drain at the bottom was found more satisfactory.

The simple adapter, shown in figure 5 , was built to hold the absorption cell, in a fixed position in the cell compartment. Care must be taken to insure that the adapter and cell compartment are rigidly

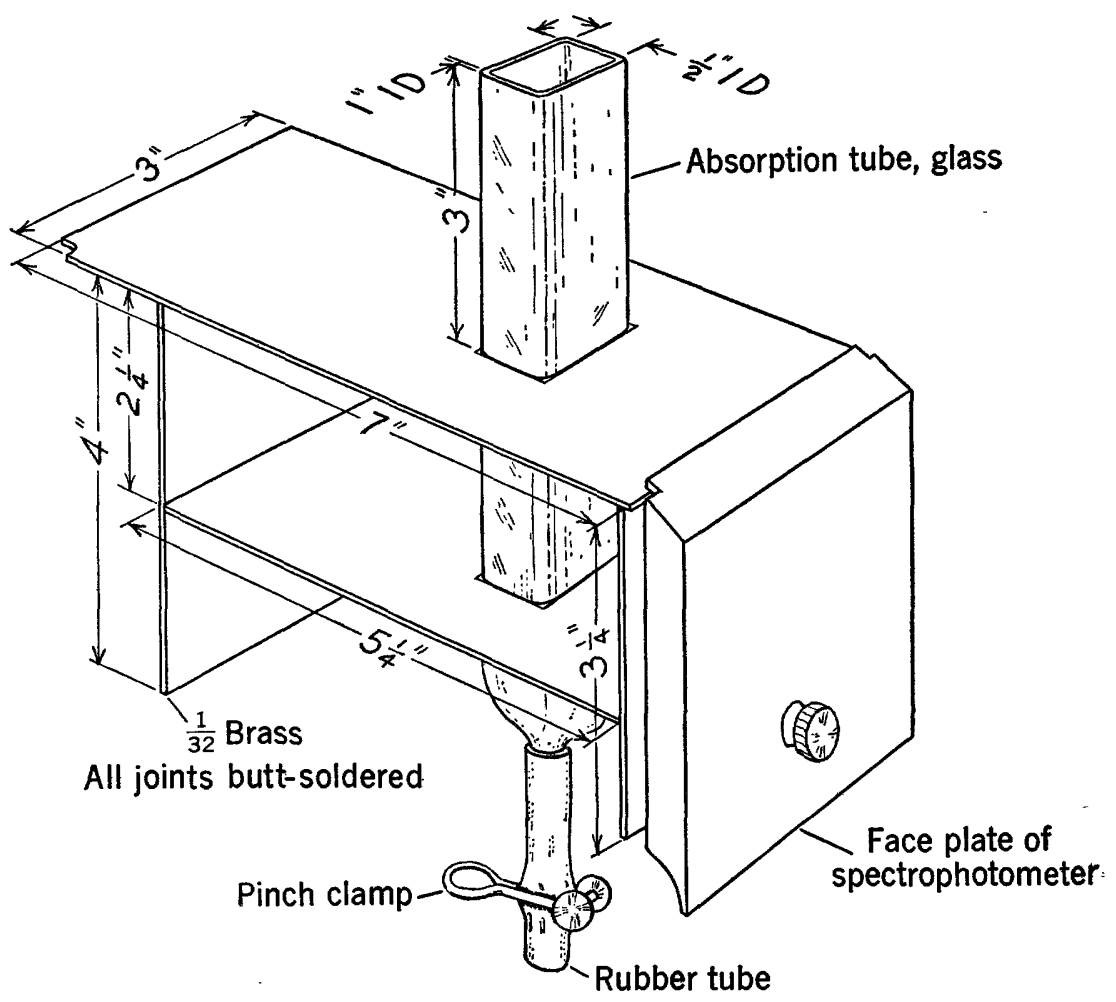

FICURE 5.-Cell and cell adapter for the spectrophotometer. 
fixed in position in order to maintain a constant light path. The absorption cell should be treated with a water-repellent to eliminate the necessity of rinsing between additions of solutions. The spectrophotometer must be raised on a platform approximately 5 in. to allow access to the absorption tube outlet.

The spectrophotometer is operated as follows: After the instrument has been allowed to warm up for about 20 minutes, pour at least $25 \mathrm{ml}$ of the reference blank solution into the absorption cell, taking care to avoid the formation of bubbles on the cell walls. This can be done simply by using a water-repellent treated funnel with a short stem bent at an angle so that the tip touches the side of the absorption cell. Set the wave length selector to the desired wave length, adjust the "dark current" reading to zero, set the sensitivity switch to position 1 , open the phototube shutter and adjust the meter to read 100 percent transmittance by varying the slit width. Close the shutter and allow the reference blank solution to drain from the absorption cell back into the original container. Carefully pour at least $25 \mathrm{ml}$ of sample solution into the absorption cell. Open the shutter and observe the meter reading. If the percent transmittance reading is less than 31.5 percent, turn the sensitivity switch to a position which gives a reading greater than 31.5 and record the meter reading and sensitivity setting. Should the reading still be less than 31.5 percent after turning the sensitivity switch to position 4 , the reading at position 4 is used. It is preferable to make the readings on the percent transmittance scale rather than the absorbance scale because readings made on the percent transmittance scale, which is graduated uniformly, are less subject to error.

For those determinations in which the spectrophotometer is used, percent transmittance readings are first converted to absorbance by interpolation of the values in table 1 (p. 50) which was derived by the use of the equation: $A$ (absorbance) $=2-\log T$ (transmittance). All calculations are then made with the absorbance values. Absorbance values are easier to use in making calculations than percent transmittance values because, when Beer's Law is followed, the absorbance is proportional to the concentration of the constituent imparting the color to the solution being analyzed and percent transmittance is not.

\section{FLAME PHOTOMETER}

The procedures described for the determination of $\mathrm{Na}_{2} \mathrm{O}$ and $\mathrm{K}_{2} \mathrm{O}$ have been worked out specifically for the Perkin-Elmer Model 52C flame photometer. Other types of flame photometers can be substituted for this instrument if the characteristics of a particular instrument are studied, and specific procedures are devised.

When the Model 52C flame photometer is used it is set up as suggested in the instruction manual, except for several minor changes. 
A special glass atomizer, shown in figure 6, is substituted for the atomizer furnished by the manufacturer, and two pressure regulators are installed in series between the propane supply and the instrument.

The capillary aspirator type of atomizer shown has certain advantages over the funnel-type atomizer when used with the flame photometer in the determination of $\mathrm{Na}_{2} \mathrm{O}$ and $\mathrm{K}_{2} \mathrm{O}$ in silicate rocks. It atomizes solution into the flame at the relatively slow fixed rate of approximately $4 \mathrm{ml}$ per minute so that a maximum of approximately $10 \mathrm{ml}$ of each sample and standard solution is consumed for each complete determination. This atomizer draws solution up through
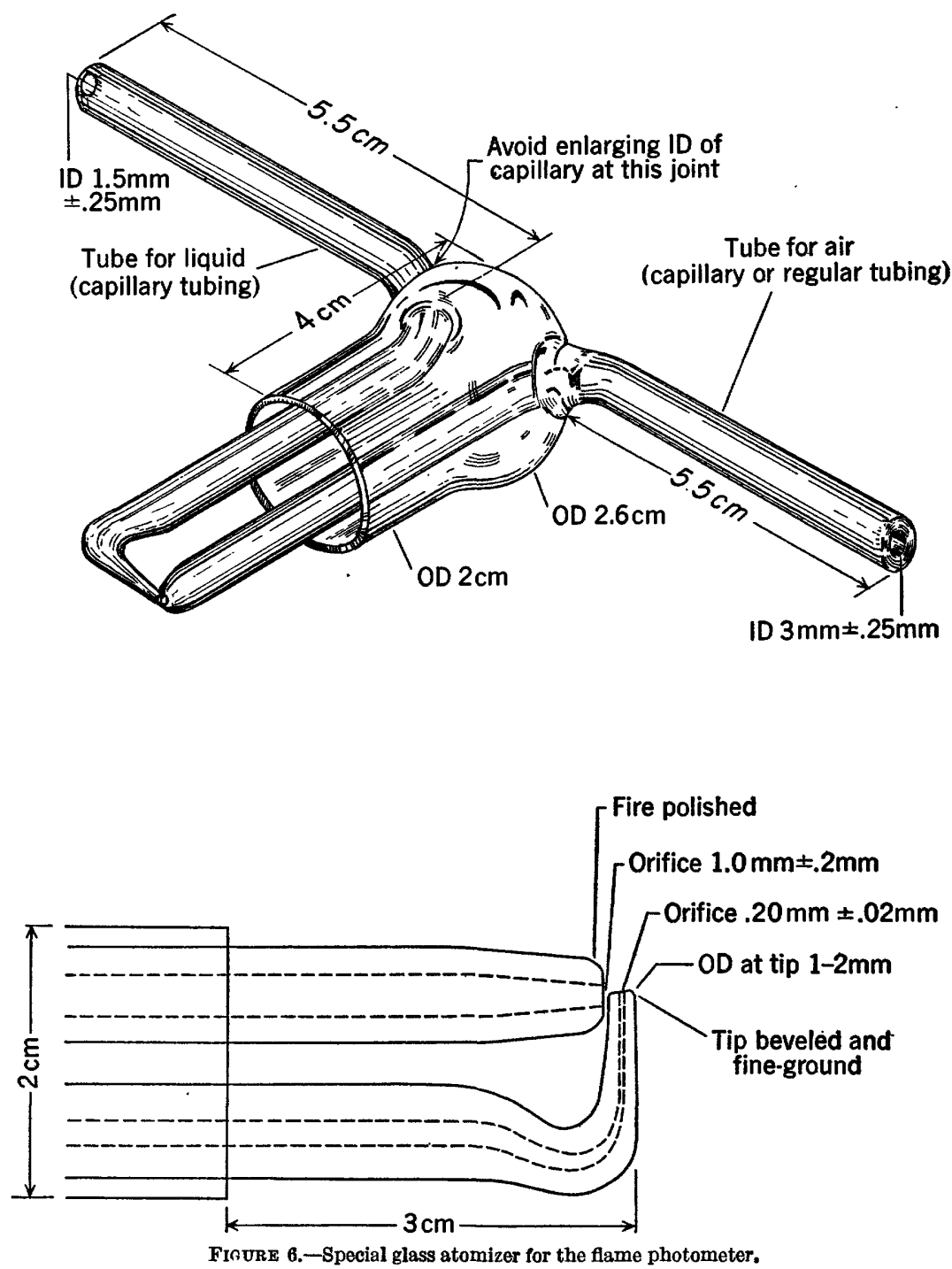
the capillary intake tube from a small beaker. When the beaker is withdrawn, the capillary tube empties in a moment. The outside of the tube can then be wiped clean with a piece of lintless tissue, another solution can be passed in, and almost immediately the capillary is flushed clean of the previous solution. There is no waiting for solutions to clear, and the deliberate rinsing and flushing, needed in using the funnel type of atomizer, is unnecessary.

Two pressure regulators, installed in the gas line, produce a relatively steady burner flame by reducing fluctuations in the gas pressure.

To start the operation of the flame photometer for the determination of $\mathrm{Na}_{2} \mathrm{O}$ and $\mathrm{K}_{2} \mathrm{O}$, first turn the electric switch on the panel of the instrument to the "on" position. Then adjust the air pressure to 10 pounds per square inch, open the main valve on the propane tank, set the gas regulator which is nearest the main valve to 10 pounds per square inch, and allow propane to pass to the burner by opening the valve on the second regulator. Light the burner and adjust the pressure, using the second gas valve, so that the flame is steady and blue with small sharply defined bright blue inner cones, which do not jump irregularly from the burner grid. The burner chimney should be shifted until the flame passes up through its center. The instrument is then allowed to warm up for about 30 minutes before readings are taken.

\section{AUTOMATIC PHOTOMETRIC TITRATION APPARATUS}

The methods described in Circular 165 for the determination of $\mathrm{CaO}$ and $\mathrm{MgO}$ in silicate rocks by Versene (disodium ethylenediamine tetraacetate) titrations have been successfully used by many analysts, nevertheless some analysts have had difficulty in discerning titration end points. These difficulties have been overcome by the use of an automatic photometric titration apparatus, shown in figure 7 . With this apparatus Versene is allowed to flow at a constant rate into the magnetically stirred solution containing the calcium or magnesium and appropriate reagents, in a beaker within the photometer. As the titration proceeds the pen-and-ink recorder plots the effect of the change in absorption, as the result of the color change of the solution, on a chart. The end point is taken as the position on the recorder chart at which change in absorption ceases. By comparing the time in seconds taken for the titration of a solution containing a known amount of calcium or magnesium with the time taken for the titration of a sample solution the amount of calcium or magnesium in the sample can be calculated.

The spectrophotometer used in the rest of the work can be adapted with an interchangeable unit to carry the titration vessel, described below, by removal of the plate below the cell compartment of the spectrophotometer. The pen-and-ink recorder described below can 
be connected to pins 11 and 13 at the rear of the instrument. If this is done the titrator is replaced by the spectrophotometer, all other circuitry remaining the same. However, where there is a substantial amount of work it is more convenient to have a separate apparatus for $\mathrm{CaO}$ and $\mathrm{MgO}$ leaving the spectrophotometer available for other work. An inexpensive titrator was designed and built for the purposealong the lines suggested by Barredo and Taylor (1947). The entire set-up is as follows (see fig. 7).

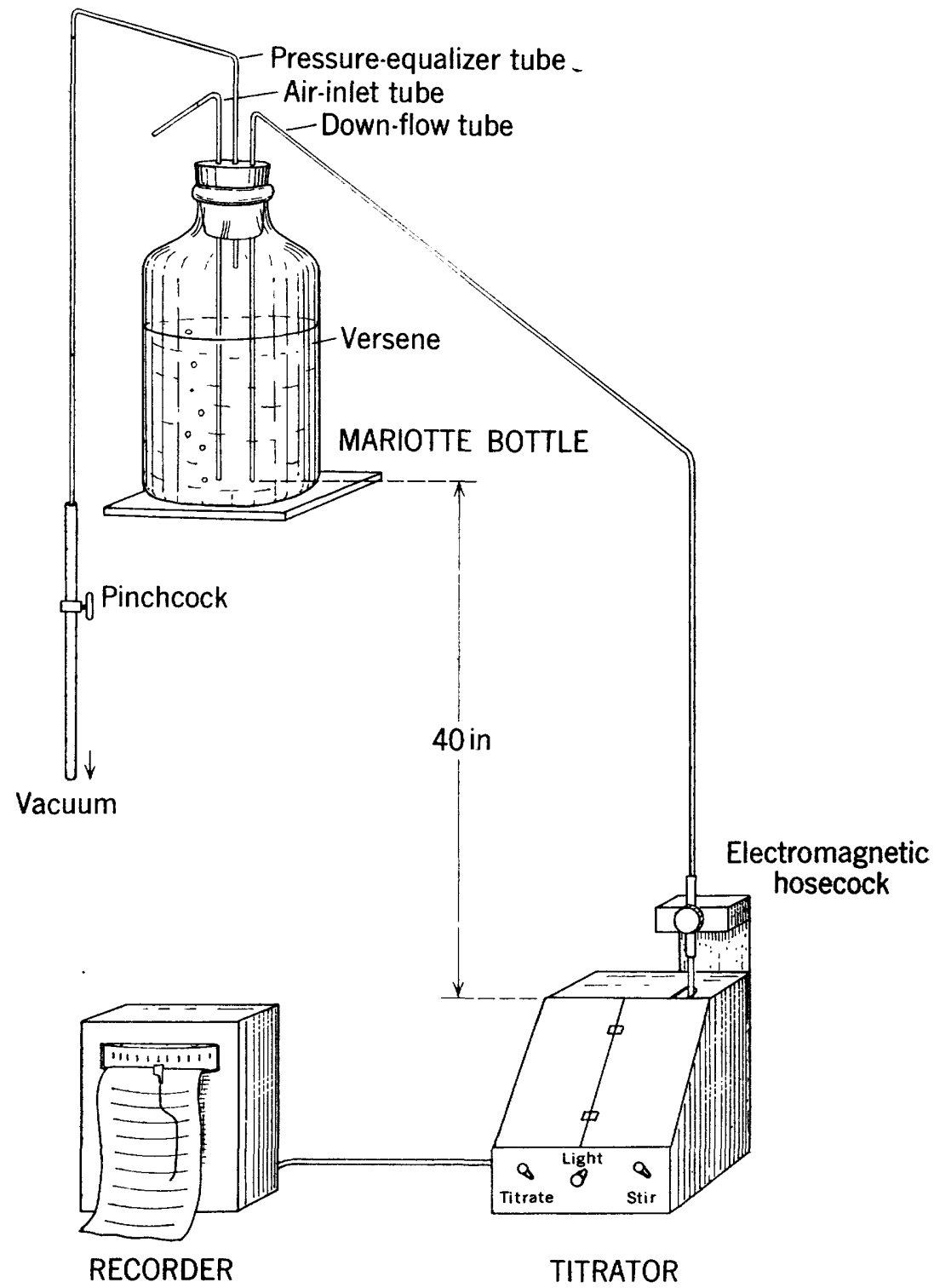

FindRe 7.-Titration assembly. 
A Mariotte bottle provides a simple means for delivery of Versene solution to a titration beaker at a constant flow rate. A 20-liter bottle is mounted on a shelf or support about 4 feet above the work bench. It is fitted with a rubber stopper through which pass three glass tubes. The air inlet tube starts at a point near the bottom of the bottle, goes through the stopper, and opens into the air. The pressure equalizer tube starts in the air space above the liquid, goes through the stopper, and is connected to a vacuum line. Somewhere along this tube is placed a rubber section with a pinchcock so that vacuum may be applied or shut off conveniently. The downflow tube starts close to the bottom of the bottle, passes through the stopper, and down to the electromagnetic hosecock which is part of the titrator. A few inches below the electromagnetic hosecock extends a capillary tube with a tip so constricted that the flow rate is maintained at 4 to $5 \mathrm{ml}$ per minute.

By this arrangement when liquid is flowing through the downflow tube the hydrostatic head is from the bottom of the air inlet tube (essentially the bottom of the bottle) to the top of the liquid in the beaker which is in the titrator. A constant head will be maintained as the liquid in the bottle is used up so long as the air pressure within the bottle is such that, as liquid is flowing out, air is entering through the air inlet and bubbling through the Versene solution. If the temperature in the room changes from day to day it may be necessary to reduce the air pressure above the liquid before the titrator is used. Vacuum is applied until air starts to bubble through the Versene solution and then the vacuum is turned off. The rubber stopper must, of course, provide an airtight seal to maintain the slight vacuum.

A pen-and-ink recorder which provides full scale deflection for 1 milliampere is used. It should have an internal resistance not exceeding $2,000 \mathrm{ohms}$. The chart drive should be geared to a feed of about 3 inches per minute at a constant rate.

The titrator shown in figure 7 is ready to use and in figure 8 the front panel is removed. The wiring diagram is given in figure 9. There are four simple circuits: the stirrer circuit (a), the titrate circuit (b), the light circuit (c), and the photocell circuit (d). The stirrer circuit consists merely of a magnetic stirrer with an on-off switch connected directly to the line current. The titrate circuit is a double-throw single-pole switch which is connected in such a way that line current is allowed to go either to the electromagnetic hosecock, or, when thrown to the opposite position, to the chart drive of the recorder. By this means coordination is achieved between the opening of the hosecock, which starts the flow of Versene, and the start of movement of the chart. The light circuit is fed from the line, through a voltage stabilizer, to the primary of a 6 - 8-volt transformer. The 
secondary of the transformer is in series with a 50-candlepower automobile light bulb and a 50-watt 5-ohm rheostat.

The photocell circuit is a series circuit involving a barrier layer selenium photocell, a $1 \frac{1}{2}$-volt dry-cell battery, and the galvanometer of the recorder. In this application, advantage is taken of the decrease in resistance of the photocell as the light intensity is increased rather than the output of the photocell itself. The polarity of the units must be correct, as shown in the diagram, or the circuit will not function. A few minutes of experimenting at this point will yield the proper arrangement. A carrier for two 2-in. by 2-in. filters is

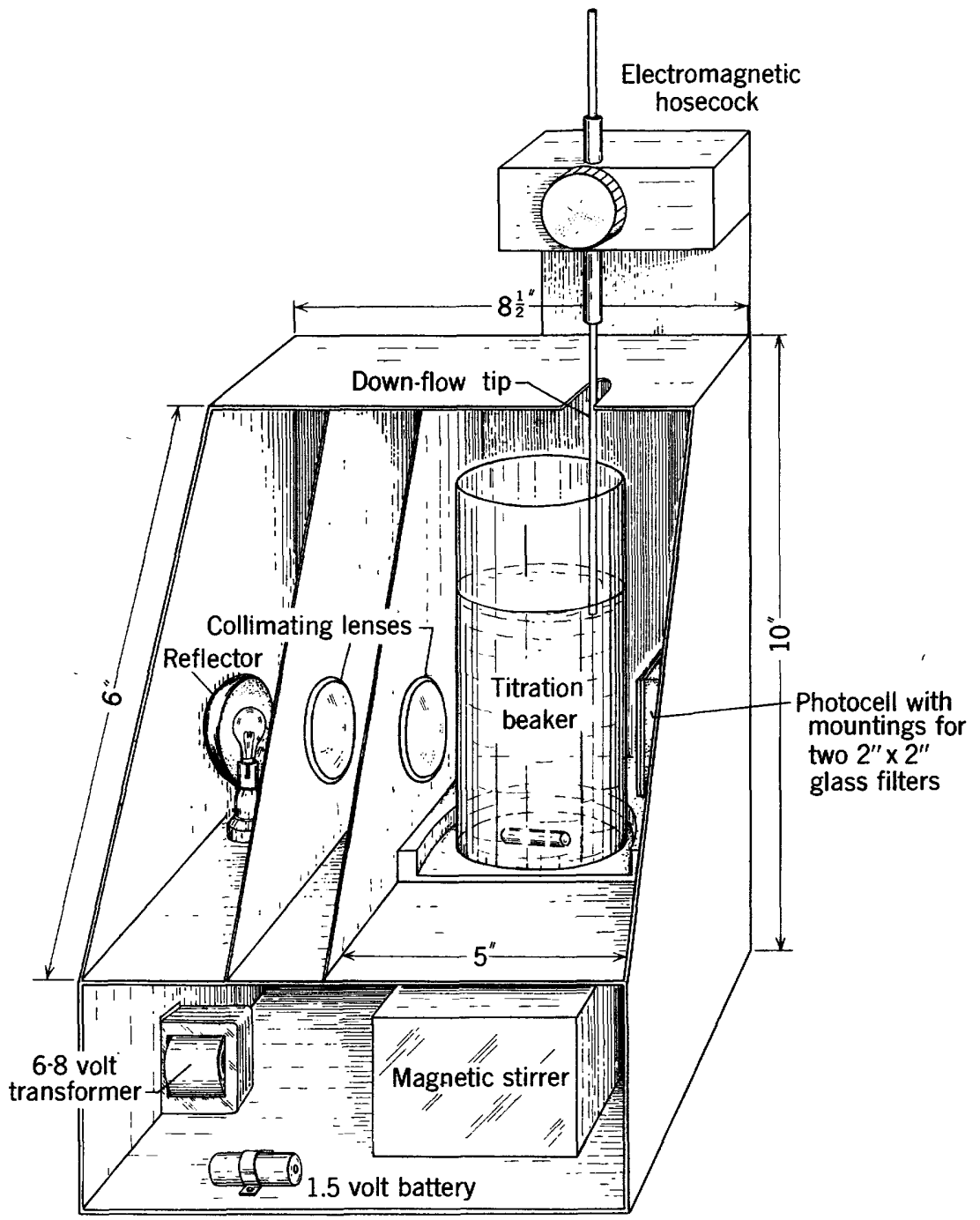

Ficure 8.-Titrator, front removed. 

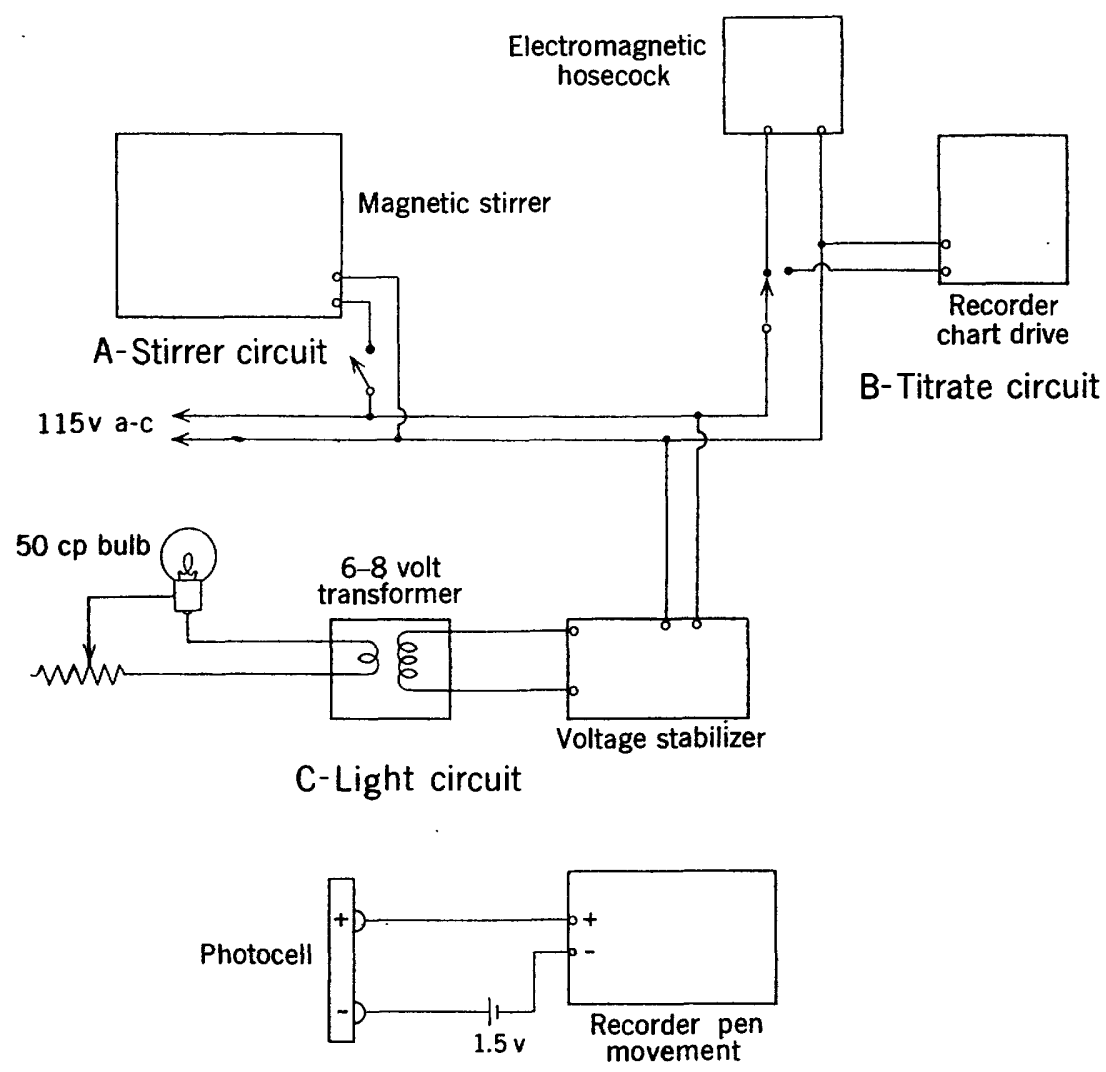

D-Photocell circuit

FindRe 9.-Circuitry of titrator.

mounted in front of the photocell. An orange filter (Corning 3480) is used in titrating $\mathrm{MgO}$, and this plus a green filter (Corning 4015) are used in titrating $\mathrm{CaO}$.

It is desirable to have several $400-\mathrm{ml}$ tall-form beakers, with lines marked off about $3 \%$ inches from the bottom of the beaker so that the same hydrostatic head is maintained from the bottom of the air inlet tube to the surface of the liquid, from beaker to beaker.

\section{CARBONATE TUBE}

The carbonate tube is a simple device designed to catch and measure the $\mathrm{CO}_{2}$ evolved from a sample upon treatment with acid. It consists of an $18 \mathrm{~mm}$ by $150 \mathrm{~mm}$ test tube with a side arm attached as shown in figure 10. 


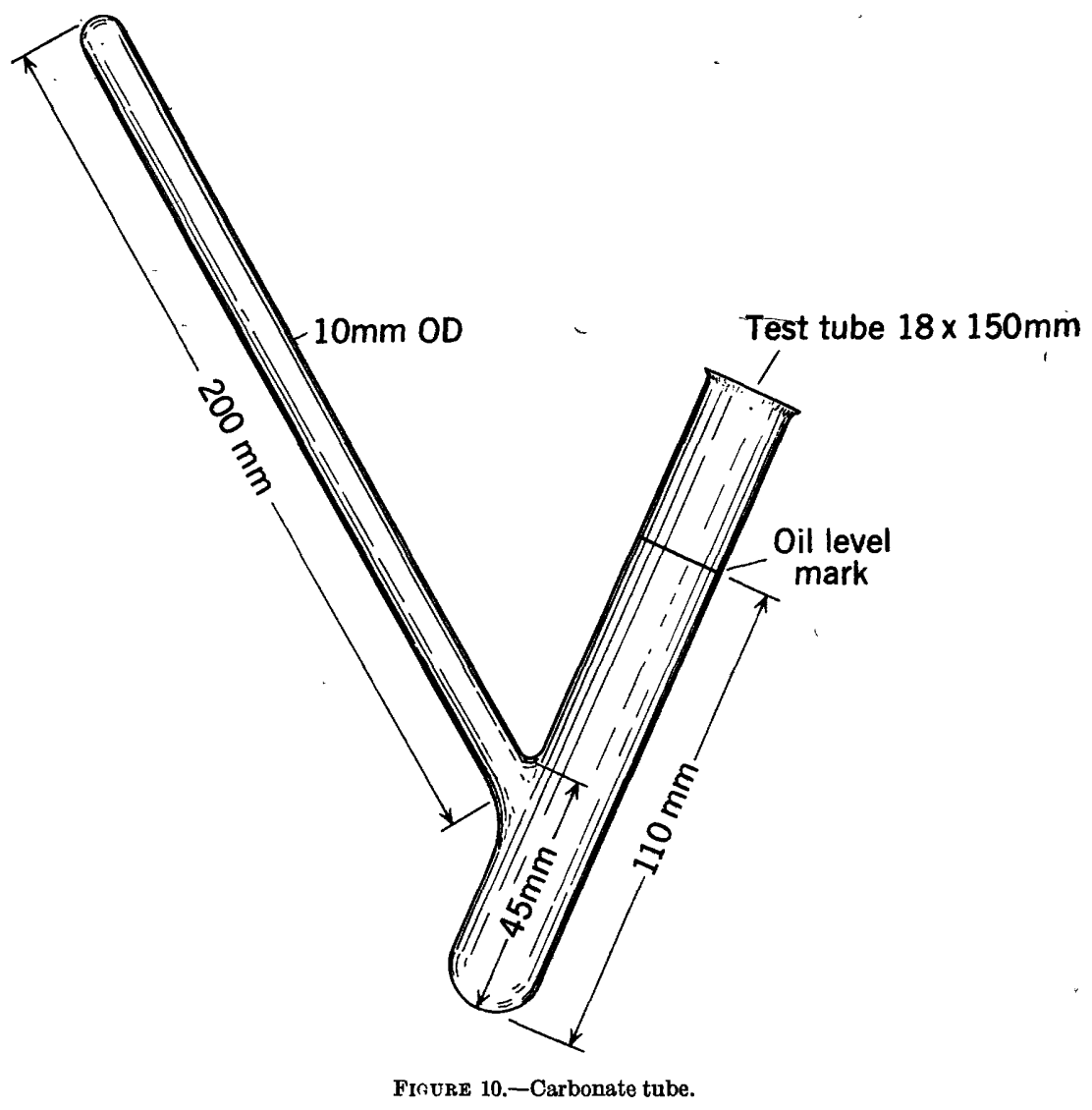

\section{PREPARATION OF SAMPLE SOLUTIONS} DISCUSSION

The major part of the analysis is made on two solutions, which are designated solution $A$ and solution $B$. (See fig. 4.)

Solution $\mathrm{A}$ is used in the determination of $\mathrm{SiO}_{2}$ and $\mathrm{Al}_{2} \mathrm{O}_{3}$. It is prepared by fusing approximately $0.0500 \mathrm{~g}$ of the sample with $\mathrm{NaOH}$ in a nickel crucible. In this way decomposition is obtained very quickly and at a comparatively low temperature. The nickel crucible is only slightly attacked, and the nickel taken into solution does not interfere with the subsequent determinations of $\mathrm{SiO}_{2}$ and $\mathrm{Al}_{2} \mathrm{O}_{3}$.

Two reference standard solutions and a reference blank solution are prepared simultaneously with solution A. National Bureau of Standards standard sample no. 99 (feldspar) is used in the preparation of the reference standard solutions. The reference blank solution is prepared in the same way as solution A except that sample powder is omitted. 
Solution $\mathrm{B}$ is used in the determinations of $\mathrm{TiO}_{2}$, total iron, $\mathrm{MnO}$, $\mathrm{P}_{2} \mathrm{O}_{5}, \mathrm{MgO}, \mathrm{CaO}, \mathrm{Na}_{2} \mathrm{O}$, and $\mathrm{K}_{2} \mathrm{O}$. To prepare this solution, a 0.400 g sample is digested overnight with $\mathrm{HF}$ and $\mathrm{H}_{2} \mathrm{SO}_{4}$ in a large covered platinum crucible on a steam bath. HF is then removed by heating until copious fumes of $\mathrm{SO}_{3}$ are given off, and the residue is dissolved in water and made to volume.

To minimize contamination from glass, the aliquots of solution $\mathrm{B}$ used for determining $\mathrm{Na}_{2} \mathrm{O}$ and $\mathrm{K}_{2} \mathrm{O}$ should be withdrawn immediately after preparation of the solution. $\mathrm{Na}_{2} \mathrm{O}$ and $\mathrm{K}_{2} \mathrm{O}$ should then be determined immediately, or the aliquots should be stored in plastic bottles.

\section{REAGENTS}

$\mathrm{NaOH}$ solution, 15 percent: Prepare 1 liter and store in a plastic bottle. $\mathrm{HF}, 48$ percent.

$\mathrm{H}_{2} \mathrm{SO}_{4}$, concentrated.

\section{SOLUTION A}

1. Transfer $10 \mathrm{ml}$ of $\mathrm{NaOH}$ solution, measured with a plastic graduated cylinder, to a nickel crucible of about 75-ml capacity. (The crucible should be cleaned with dilute $\mathrm{HCl}$ before using.)

2. Transfer $10 \mathrm{ml}$ of $\mathrm{NaOH}$ to each of three additional clean nickel crucibles for preparation of two reference standard solutions and a reference blank solution.

3. Evaporate the solutions to dryness over gas burners or electric heaters. A slight amount of spattering can be ignored.

4. Accurately weigh (to the nearest $0.1 \mathrm{mg}$ ) approximately $0.0500 \mathrm{~g}$ of sample powder (ground to pass a 100-mesh screen) and two portions of National Bureau of Standards standard sample no. 99. Transfer each portion of powder to an individual crucible containing $\mathrm{NaOH}$. Exactly $0.0500-\mathrm{g}$ sample portions can be weighed if desired. In this way the ultimate calculation of percent $\mathrm{SiO}_{2}$ and percent $\mathrm{Al}_{2} \mathrm{O}_{3}$ can be simplified, but in so doing the total time required for the determinations may be increased appreciably.

5. Cover and heat all of the crucibles to dull redness for about 5 minutes. Remove each crucible from the heat and swirl the melt around the sides. Allow the melts to cool.

6. Add approximately $50 \mathrm{ml}$ of water to each crucible, cover, and allow to stand overnight.

7. Transfer the contents of the crucibles to beakers containing about $400 \mathrm{ml}$ of distilled water and $20 \mathrm{ml}$ of $1+1 \mathrm{HCl}$. Scrub each crucible with a rubber policeman and wash any remaining solution or residue into the appropriate beaker. (Do not allow the nickel crucibles to come in contact with the acid solutions.)

8. Transfer the solutions to individual 1-liter volumetric flasks, dilute to 1 liter with distilled water, and mix well. (The flasks should be cleaned with $1+1 \mathrm{HCl}$ before use.)

\section{SOLUTION B}

1. Transfer a $0.400-\mathrm{g}$ sample to a platinum crucible of about $100-\mathrm{ml}$ capacity.

2. Add $10 \mathrm{ml}$ of $\mathrm{HF}$.

3. Add $3 \mathrm{ml}$ of $\mathrm{H}_{2} \mathrm{SO}_{4}$.

4. Cover the crucible with a platinum cover and digest overnight on a steam bath.

5. Remove the cover, allow the crucible to heat on the steam bath until the volume of liquid is reduced to about $3 \mathrm{ml}$, and add about $1 \mathrm{ml}$ of $\mathrm{HNO}_{3}$. 
6. Place the crucible over an electric heater or gas burner and heat until strong $\mathrm{SO}_{3}$ fumes evolve.

7. Allow the crucible and contents to cool.

8. Fill the crucible with distilled water, cover, and digest on the steam bath until the residue dissolves. If a residue remains after digesting for about half an hour, transfer solution and residue to a $400-\mathrm{ml}$ Vycor beaker and boil gently for 10 to 15 minutes. If a small insoluble residue remains, it may be barium sulfate, zircon, or possibly tourmaline. This may be filtered off and discarded because $\mathrm{BaO}$ and $\mathrm{ZrO}_{2}$ are not determined. Tourmaline is usually not found in more than trivial quantities.

9. Transfer the solution to a $200-\mathrm{ml}$ volumetric flask, dilute to volume, and mix well.

10. Immediately withdraw $25 \mathrm{ml}$ of the solution with a pipet and transfer to a 150-ml Pyrex beaker or Pyrex bottle if $\mathrm{Na}_{2} \mathrm{O}$ can be determined the same day, or, if $\mathrm{Na}_{2} \mathrm{O}$ cannot be determined the same day, transfer the aliquot to a plastic bottle to eliminate the possibility of alkali contamination from the container.

\section{METHODS}

\section{$\mathrm{SiO}_{2}$}

In the determination of $\mathrm{SiO}_{2}$ (Bunting, 1944) the yellow silicomolybdate complex is reduced to molybdenum blue and the transmission of light is measured at $650 \mathrm{~m} \mu$. As silica is the predominant constituent in silicate rocks, relatively more precise values are desired for $\mathrm{SiO}_{2}$ than for the constituents present in lower concentrations. For this reason sample weighings, volume measurements, and spectrophotometer readings must be made very carefully.

\section{REAGFNTS}

Ammonium molybdate reagent solution: Dissolve $7.5 \mathrm{~g}$ of ammonium molybdate in $75 \mathrm{ml}$ of water. Add $10 \mathrm{ml}$ of $1+1 \mathrm{H}_{2} \mathrm{SO}_{4}$ and dilute to $100 \mathrm{ml}$. Store in a plastic bottle.

Tartaric acid solution, 10 percent: Prepare $500 \mathrm{ml}$ and store in a plastic bottle. Discard and prepare fresh solution when an appreciable amount of sediment forms.

Reducing solution: Dissolve $0.7 \mathrm{~g}$ of sodium sulfite in $10 \mathrm{ml}$ of water. Add 0.15 $\mathrm{g}$ of 1-amino-2-napthol-4-sulfonic acid and stir until dissolved. Dissolve $9 \mathrm{~g}$ of sodium bisulphite in $90 \mathrm{ml}$ of water and add this solution to the solution above and mix. Store in plastic bottle.

\section{PROCFDURE}

1. Withdraw $10 \mathrm{ml}$ of sample solution $\mathrm{A}, 10 \mathrm{ml}$ of each reference standard solution, and $10 \mathrm{ml}$ of the solution A blank solution (see Preparation of sample solution, Solution A, step 8) with a pipet, and transfer each aliquot to a separate 100-ml volumetric flask which has been cleaned with $1+1 \mathrm{HCl}$.

2. Add $1 \mathrm{ml}$ of the ammonium molybdate reagent solution with a pipet, swirling the flasks during the additions. Mix well and allow to stand for 10 minutes.

3. Add $4 \mathrm{ml}$ of the tartaric acid solution with a pipet, swirling the flasks while adding and mix well.

4. Add $1 \mathrm{ml}$ of the reducing solution with a pipet, while swirling the flasks, dilute to volume, mix well, and allow to stand at least 30 minutes. 
5. Determine the percent transmission for each solution at $650 \mathrm{~m} \mu$ using the solution prepared from the solution $A$ blank solution as the reference blank solution.

\section{CaLCULatrons}

1. Convert each of the values obtained for percent transmission to absorbance using table 1.

2. Calculate all of the absorbance values to a 50-mg sample-weight basis using the original sample weights (Solution A, step 4):

Absorbance $\times \frac{50}{\text { sample weight }}=$ absorbance on a 50-mg sample-weight basis.

3. Compute a factor for each of the two comparison standards:

$$
\frac{\text { Percent } \mathrm{SiO}_{2} \text { of comparison standard }}{\text { Absorbance of comparison standard (on 50-mg basis) }}=\text { factor. }
$$

4. Calculate an average from the two factors.

5. Compute the percent $\mathrm{SiO}_{2}$ in the sample:

(Averoge factor) $\times$ (absorbance of sample solution, on $50-\mathrm{mg}$ basis $)=$ percent $\mathrm{SiO}_{2}$

$\mathrm{Al}_{2} \mathrm{O}_{3}$

Alumina $\left(\mathrm{Al}_{2} \mathrm{O}_{3}\right)$ is determined by measuring the transmission of light at $475 \mathrm{~m} \mu$ of a solution containing the complex of aluminum, calcium, and alizarin red-S (Parker and Goddard, 1950). This complex has been found to have a much greater absorption, for a given amount of aluminum, than the complex formed by aluminum and alizarin red-S alone. Complexes, which absorb light at 475 $\mathrm{m} \mu$, are also formed by iron and titanium with calcium and alizarin red-S. The effect of iron is eliminated by the formation of ferrous ferricyanide prior to adding alizarin red-S solution to the sample solution. The effect of titanium is found empirically and a comparatively small correction, based on the determined $\mathrm{TiO}_{2}$ value, is subtracted from the apparent value for percent $\mathrm{Al}_{2} \mathrm{O}_{3}$ obtained from the total absorption at $475 \mathrm{~m} \mu$.

It has been empirically determined that for each percent $\mathrm{TiO}_{2}$ in the sample an apparent increase of 0.5 percent $\mathrm{Al}_{2} \mathrm{O}_{3}$ results. The correction for $\mathrm{TiO}_{2}$ can then be made simply by subtracting one-half the percent of $\mathrm{TiO}_{2}$, as determined under Determination of $\mathrm{TiO}_{2}$, from the apparent percent $\mathrm{Al}_{2} \mathrm{O}_{3}$.

\section{REAGENTS}

Hydroxylamine hydrochloride solution, 10 percent: Prepare $500 \mathrm{ml}$.

Calcium chloride solution: Transfer approximately $7 \mathrm{~g} \mathrm{CaCO}_{3}$ to a $250-\mathrm{ml}$ beaker. Add about $50 \mathrm{ml}$ of water. Add dilute $\mathrm{HCl}$, dropwise, with stirring, until the $\mathrm{CaCO}_{3}$ is dissolved. Boil the solution for 1 to 2 minutes. Cool and dilute to about $500 \mathrm{ml}$.

Potassium ferricyanide solution, 1 percent: Prepare $100 \mathrm{ml}$. Do not store for more than 1 day. 
Buffer solution: $70 \mathrm{~g}$ of sodium acetate and $30 \mathrm{ml}$ of glacial acetic acid diluted to $500 \mathrm{ml}$ with distilled water.

Alizarin red-S solution, 0.1 percent: Prepare $500 \mathrm{ml}$.

\section{PROCEDURE}

1. Withdraw $20 \mathrm{ml}$ of sample solution $\mathrm{A}, 20 \mathrm{ml}$ of each reference standard solution, and $20 \mathrm{ml}$ of the solution A blank solution (Preparation of sample solution, Solution A, step 8), with a pipet and transfer to individual $100-\mathrm{ml}$ volumetric flasks which have been cleaned with $1+1 \mathrm{HCl}$ and subsequently rinsed with water.

2. Add $1 \mathrm{ml}$ of the $\mathrm{CaCl}_{2}$ solution to each of the flasks and mix.

3. Add $1 \mathrm{ml}$ of the hydroxylamine hydrochloride solution to each flask and mix.

4. Add $1 \mathrm{ml}$ of the potassium ferricyanide to each flask, mix, and allow to stand for 5 minutes.

5. Add $10 \mathrm{ml}$ of the buffer solution measured with a graduate to each flask, mix, and allow to stand 10 minutes.

6. Add $5 \mathrm{ml}$ of the alizarin red-S solution to each flask, dilute to $100 \mathrm{ml}$ with distilled water, mix, and allow to stand for 1 to 2 hours.

7. Determine the percent transmission at $475 \mathrm{~m} \mu$ for the sample solution and the two comparison standard solutions using the solution prepared from the solution A blank solution as the reference blank solution.

\section{CALCULATIONS}

1. Convert each of the values obtained for percent transmission to absorbance using table 1.

2. Calculate the absorbance values to a 50-mg sample-weight basis:

Absorbance $\times \frac{50}{\text { sample weight (mg) }}=$ absorbance on a 50 -mg weight basis.

3. Compute a factor for each of the two comparison standards: $\frac{\text { Percent } \mathrm{Al}_{2} \mathrm{O}_{3} \text { of comparison standard }}{\text { Absorbance of comparison standard (on } 50 \mathrm{mg} \text { weight basis) }}=$ factor.

4. Calculate an average factor from the two factors.

5. Compute the apparent percent $\mathrm{Al}_{2} \mathrm{O}_{3}$ in the sample:

Average factor $X$ absorbance of sample solution (on $50 \mathrm{-mg}$ weight basis) =apparent percent $\mathrm{Al}_{2} \mathrm{O}_{3}$.

6. To obtain the percent $\mathrm{Al}_{2} \mathrm{O}_{3}$ in the sample, subtract the correction for $\mathrm{TiO}_{2}$ effect:

(Apparent percent $\left.\mathrm{Al}_{2} \mathrm{O}_{3}\right)-1 / 2$ (percent $\mathrm{TiO}_{2}$ in the sample)= pereent $\mathrm{Al}_{2} \mathrm{O}_{3}$.

Note: The procedure described above for the determination of $\mathrm{Al}_{2} \mathrm{O}_{3}$ tends to give low results for samples containing more than 20 percent $\mathrm{Al}_{2} \mathrm{O}_{3}$. For samples of this type, which are rare, the difficulty can be overcome by using $10 \mathrm{ml}$ of solution A plus $10 \mathrm{ml}$ of solution A blank solution in the same flask, instead of the usual 20-ml aliquot of solution A. The $10 \mathrm{ml}$ of the solution A blank solution is added so that the correct $\mathrm{pH}$ will be maintained.

\section{TOTAL IRON AS $\mathrm{Fe}_{2} \mathrm{O}_{3}$}

Total iron is determined by measuring the transmission of light at $560 \mathrm{~m} \mu$ of a solution containing the orange ferrous orthophenanthroline complex (Bandemer and Schaible, 1944). This procedure is simple and highly reliable. 


\section{REAGENTS}

Hydroxylamine hydrochloride, 10 percent: Prepare $500 \mathrm{ml}$. Orthophenathroline solution, 0.1 percent: Prepare $500 \mathrm{ml}$.

Sodium citrate solution, 10 percent: Prepare $500 \mathrm{ml}$.

Standard iron solution: Weigh $0.491 \mathrm{~g} \mathrm{FeSO}$ $500 \mathrm{ml}$ volumetric fiask. Add $3 \mathrm{ml}$ of $1+1 \mathrm{H}_{2} \mathrm{SO}_{4}$ and about $300 \mathrm{ml}$ of water. Stir until completely dissolved, then add water to the mark, and mix. The $\mathrm{Fe}_{2} \mathrm{O}_{3}$ concentration in this solution is $0.2 \mathrm{mg}$ per $\mathrm{ml}$, which is equivalent to that in a solution prepared from a sample containing 10.00 percent $\mathrm{Fe}_{2} \mathrm{O}_{3}$, as directed under Preparation of sample solution, solution $B$.

\section{PROCEDURE}

1. To a set of $100-\mathrm{ml}$ volumetric flasks, add nothing to the first flask (to serve as a blank), $5 \mathrm{ml}$ of the standard iron solution to the second flask, and $5 \mathrm{ml}$ of sample solution $B$ to the third flask. (The aliquots should be measured with a pipet.)

2. Add $5 \mathrm{ml}$ of the hydroxylamine hydrochloride solution to each flask with a graduated cylinder and allow to stand for 10 minutes.

3. Add $10 \mathrm{ml}$ of the orthophenanthroline solution with a graduated cylinder.

4. Add $10 \mathrm{ml}$ of the sodium citrate solution with a graduated cylinder.

5. Dilute to $100 \mathrm{ml}$ with distilled water and mix.

6. After one hour determine the percent transmission at $560 \mathrm{~m} \mu$, for the sample and standard solutions using the reagent blank as the reference blank solution.

\section{CALCULATIONS}

1. Convert each of the values obtained for percent transmission to absorbance using table 1.

2. Compute the factor for the standard solution:

$$
\frac{10}{\text { Absorbance of the standard solution }}=\text { factor. }
$$

3. Compute percent total iron as $\mathrm{Fe}_{2} \mathrm{O}_{3}$ :

(Factor) $\times($ absorbance of sample solution $)=$ percent total $\mathrm{Fe}$ as $\mathrm{Fe}_{2} \mathrm{O}_{3}$.

Note: Percent $\mathrm{Fe}_{2} \mathrm{O}_{3}$ in the sample is calculated in the usual way by subtracting the $\mathrm{Fe}_{2} \mathrm{O}_{3}$ equivalent of $\mathrm{FeO}$ (separately determined) from the value for total $\mathrm{Fe}$ as $\mathrm{Fe}_{2} \mathrm{O}_{3}$ :

(Percent total $\mathrm{Fe}$ as $\mathrm{Fe}_{2} \mathrm{O}_{3}$ )- (percent $\mathrm{FeO} \times 1.1$ ) $=$ percent $\mathrm{Fe}_{2} \mathrm{O}_{3}$.

$$
\mathrm{TiO}_{2}
$$

To determine $\mathrm{TiO}_{2}$ measure the transmission of light at $430 \mathrm{~m} \mu$ by solutions containing the yellow complex produced by the reaction of titanium with tiron (disodium-1, 2-dihydroxybenzene-3, 5-disulfonate) (Yoe and Armstrong, 1947).

\section{REAGENTS}

Tiron (disodium-1, 2-dihydroxybenzene-3, 5-disulfonate): Dry reagent powder. Buffer solution: $40 \mathrm{~g}$ of ammonium acetate and $15 \mathrm{ml}$ of glacial acetic acid made to 1 liter with distilled water.

Sodium dithionite, $\mathrm{Na}_{2} \mathrm{~S}_{2} \mathrm{O}_{4}$ (sometimes sold as sodium hydrosulphite): Dry reagent powder. 
Standard $\mathrm{TiO}_{2}$ solution: Weigh $0.1013 \mathrm{~g}$ of National Bureau of Standards standard sample no. 154 (titanium dioxide) or the appropriate amount of reagent $\mathrm{TiO}_{2}$ of known composition. Transfer to a small platinum crucible. Add $2 \mathrm{~g}$ of sodium bisulphate, cover, and heat until the sample is completely fused. Allow to cool and place the crucible into a beaker containing $50 \mathrm{ml}$ of $1+1 \mathrm{H}_{2} \mathrm{SO}_{4}$. Heat and stir until the melt is completely dissolved. Cool, dilute the solution to $250 \mathrm{ml}$ in a volumetric flask, and mix well. Transfer $50 \mathrm{ml}$ of the solution with a pipet to a 1-liter volumetric flask, dilute to the mark, and mix. Store the solution in a glass-stoppered bottle. The concentration of $\mathrm{TiO}_{2}$ is $0.02 \mathrm{mg}$ per $\mathrm{ml}$ which is equivalent to that in a solution prepared from a sample containing 1.00 percent $\mathrm{TiO}_{2}$, as directed under Preparation of sample solution, solution B.

\section{PROCEDURE}

1. To the first of a series of dry $100-\mathrm{ml}$ beakers add $5 \mathrm{ml}$ of water, to the second add $5 \mathrm{ml}$ of the standard $\mathrm{TiO}_{2}$ solution, and to the third add $5 \mathrm{ml}$ of sample solution B. Use a pipet for the measurements.

2. With a small scoop add about $130 \mathrm{mg}$ of dry tiron powder to each beaker.

3. With a pipet add $50 \mathrm{ml}$ of the buffer solution to each solution and mix.

4. Set the spectrophotometer to $430 \mathrm{~m} \mu$. Add about 10 to $20 \mathrm{mg}$ of sodium dithionite powder to the solution to be used as a reagent blank solution and mix gently by rotating the beaker two or three times. Do not overmix.

5. After about $\hat{1}$ minute pour the solution into the absorption cell and adjust the slit width to give 100 percent transmission.

6. Repeat with each solution, adding dithionite, waiting about 1 minute, and reading percent transmission.

\section{CaLCULATTONS}

1. Convert each of the values obtained for percent transmission to absorbance using table 1.

2. Compute the factor for the standard solution:

$$
\frac{1}{\text { Absorbance of standard solution }}=\text { factor. }
$$

3. Compute percent $\mathrm{TiO}_{2}$ :

(Factor) $\times($ absorbance of sample solution $)=$ percent $\mathrm{TiO}_{2}$.

$$
\mathbf{P}_{2} \mathbf{O}_{6}
$$

The phosphate content of a sample is deterınined by measuring the light transinitted at $430 \mathrm{~m} \mu$ by a solution containing the yellow molybdivanadophosphoric acid coinplex (Kitson and Mellon, 1944).

\section{REAGEN'TS}

Molybdivanadate solution: Dissolve $1.25 \mathrm{~g}$ of ammonium metavanadate in $400 \mathrm{ml}$ of $1+1 \mathrm{HNO}_{3}$. Dissolve $50 \mathrm{~g}$ of ammonium molybdate in $400 \mathrm{ml}$ of water. Mix the solutions and make up to 1 liter with water.

Standard $\mathrm{P}_{2} \mathrm{O}_{5}$ solution: Transfer $0.0849 \mathrm{~g}$ of National Bureau of Standards standard phosphate rock no. 120 to a $150-\mathrm{ml}$ beaker and add $25 \mathrm{ml}$ of $1+1$ $\mathrm{HNO}_{3}$. Digest on a steam bath until solution is essentially complete. Cool and make up to 2 liters in a volumetric flask. Store in a glass-stoppered bottle. The concentration of $\mathrm{P}_{2} \mathrm{O}_{5}$ is $0.015 \mathrm{mg}$ per $\mathrm{ml}$ which is equivalent to that in a solution prepared from a sample containing 0.75 percent $\mathrm{P}_{2} \mathrm{O}_{5}$ as directed under Preparation of sample solution, solution B. 


\section{PROCEDURE}

1. With a pipet transfer a $15-\mathrm{ml}$ aliquot of sample solution $B$ to a $100-\mathrm{ml}$ beaker. At the same time transfer $15 \mathrm{ml}$ of water and $15 \mathrm{ml}$ of the standard solution to two additional beakers, for a blank and standard.

2. Add $10 \mathrm{ml}$ of the molybdivanadate solution to each solution with a pipet, swirling the solutions during the additions. Add $25 \mathrm{ml}$ of water with a pipet, mix, and allow to stand for at least 5 minutes.

3. Determine the percent transmission, at $430 \mathrm{~m} \mu$ for each solution using the reagent blank solution as the reference blank solution.

\section{CALCULATIONS}

1. Convert the readings for percent transmission to absorbance using table 1 .

2. Compute a factor:

$$
\frac{0.75}{\text { Absorbance of standard solution }}=\text { factor. }
$$

3. Calculate percent $\mathrm{P}_{2} \mathrm{O}_{5}$ :

(Factor) $\times$ (absorbance of sample solution $)=$ percent $\mathrm{P}_{2} \mathrm{O}_{3}$.

Mno

Manganese oxide is determined by measuring the light transmitted at $525 \mathrm{~m} \mu$ by a sample solution in which the manganese has been oxidized to permanganate with $\mathrm{KIO}_{4}$ (Willard and Greathouse, 1917).

KIO : Dry powder.

\section{REAGENTS}

Acid mixture: Water solution containing 10 percent $\mathrm{H}_{3} \mathrm{PO}$ and 25 percent $\mathrm{H}_{2} \mathrm{SO}_{4}$ by volume, 2 liters.

Standard MnO solution: Transfer $0.0531 \mathrm{~g}$ of National Bureau of Standards standard sample no $25 \mathrm{~b}$ (manganese ore) to a $250-\mathrm{ml}$ beaker. Add $25 \mathrm{ml}$ of $1+1 \mathrm{HNO}_{3}$ and 2 to $3 \mathrm{ml}$ of 3 percent $\mathrm{H}_{2} \mathrm{O}_{2}$. Digest on a steam bath until no black residue remains. Cool and add $50 \mathrm{ml}$ of $\mathrm{H}_{2} \mathrm{SO}_{4}$. Evaporate and continue heating until fumes of $\mathrm{SO}_{3}$ are evolved. Cool and dilute to approximately 200-ml volume. If necessary warm to dissolve. Cool and dilute to 2 liters. Store in glass-stoppered bottle. The $\mathrm{MnO}$ content is $0.02 \mathrm{mg}$ per $\mathrm{ml}$ which is equal to that in a solution prepared from a sample containing 1.0 percent $\mathrm{MnO}$ as directed under Preparation of sample solution, solution $\mathrm{B}$.

\section{PROCEDURE}

1. Transfer a $20-\mathrm{ml}$ aliquot of solution $B$ to a $250-\mathrm{ml}$ beaker. To two additional beakers transfer $20 \mathrm{ml}$ of water and $20 \mathrm{ml}$ of standard $\mathrm{MnO}$ solution to serve as a reagent blank solution and standard solution.

2. Add $50 \mathrm{ml}$ of acid mixture.

3. Add approximately $0.2 \mathrm{~g}$ of $\mathrm{KIO}_{4}$.

4. Cover the beakers, and bring to a boil. Keep at the boiling point for 5 minutes.

5. Cool the solutions to room temperature in a water bath.

6. Transfer the solutions to $100-\mathrm{ml}$ volumetric flasks, dilute to volume and mix well.

7. Measure the percent transmission at $525 \mathrm{~m} \mu$ using the reagent blank solution as the reference. 


\section{CALCULATIONS}

1. Convert each of the values for percent transmission to absorbance using table 1.

2. Compute the factor:

$$
\frac{1.0}{\text { Absorbance of the standard solution }}=\text { factor. }
$$

3. Calculate percent $\mathrm{MnO}$ :

(Factor $) \times($ absorbance of sample solution $)=$ percent $\mathrm{MnO}$.

\section{$\mathrm{CaO}$}

Calcium oxide is determined by titration with disodium ethylenediamine tetraacetate (Versene) using murexide (ammonium pupurate) as an indicator (Betz and Noll, 1950). Iron and aluminum are complexed with sodium potassium tartrate and do not interfere. The titration is carried out automatically; the change in color of the indicator solution is recorded with a pen-and-ink recorder as the titration proceeds. The apparatus used is described under Apparatus and instruments.

\section{REAGENTS}

Versene solution: Dissolve $20 \mathrm{~g}$ of disodium ethylenediamine tetraacetate in 20 liters of water and transfer to the Mariotte bottle.

$\mathrm{NaOH}$ solution, 15 percent: Prepare 1 liter and store in a plastic bottle.

Murexide indicator solution approximately 0.2 percent: Prepare $50 \mathrm{ml}$.

This solution should not be kept for more than three days.

Sodium potassium tartrate, 20 percent: Prepare $500 \mathrm{ml}$.

Standard $\mathrm{CaO}$ solution: Transfer $1.000 \mathrm{~g}$ of Bureau of Standards standard sample no. 88 (dolomite) to a 250-ml beaker. Add $20 \mathrm{ml}$ of $\mathrm{HCl} \mathrm{1+1,}$ cover, and boil 3 to 5 minutes. Cool to room temperature and dilute to 1 liter in a volumetric flask. The solution contains the equivalent of $0.305 \mathrm{mg}$ of $\mathrm{CaO}$ per $\mathrm{ml}$. Store the solution in a plastic bottle.

\section{PROCEDURE}

1. Transfer $1 \mathrm{ml}$ of the standard $\mathrm{CaO}$ solution to a $400-\mathrm{ml}$ tall form titration beaker.

2. Fill the beaker to the mark with distilled water.

3. Place the titration vessel into the titrator in position for titration, add a plastic coated magnet, and start the stirrer.

4. Add $3 \mathrm{ml}$ of the sodium potassium tartrate solution.

5. Add $10 \mathrm{ml}$ of the $\mathrm{NaOH}$ solution.

6. Add $1 \mathrm{ml}$ of the murexide indicator solution.

7. Insert the delivery tip into the beaker, check to see if both the orange and green filters are in front of the photocell, and close the cover. (If a spectrophotometer is used, set to $590 \mathrm{~m} \mu$.)

8. Adjust the light to maximum intensity and then reduce it slightly so that the last movement of the pen of the recorder is from right to left.

9. Throw the toggle switch permitting the electromagnetic hosecock to open and the recorder to start. 
10. As the titration proceeds the pen which is tracing out the curve moves to the left as the color changes. (See fig. 11.) When sufficient Versene solution has flowed into the beaker to react completely with the calcium the pen will no longer move to the left but will trace a line parallel with the chart movement. Allow the chart to move about 1 inch past this point, turn all switches to "off" and remove the beaker.

11. Transfer $10 \mathrm{ml}$ of the standard $\mathrm{CaO}$ solution to a $400-\mathrm{ml}$ titration beaker and repeat steps 2 through 10 . 10.

12. Transfer $10 \mathrm{ml}$ of solution $B$ to a $400-\mathrm{ml}$ beaker and repeat steps 2 through

13. The curves are used to obtain the end point of the titrations as illustrated in figure 11. A ruled line is extended from the last portion of the curve (the flat portion) and another ruled line is extended along the portion of the curve immediately in front of the sudden change of direction. The intersection of the ruled lines is the end point. The time, in seconds, required for the titration is measured from starting line to the end point. If the chart has lines every $3 / 4 \mathrm{in}$., then the distance between lines represents 15 seconds. Each titration is expressed in seconds.

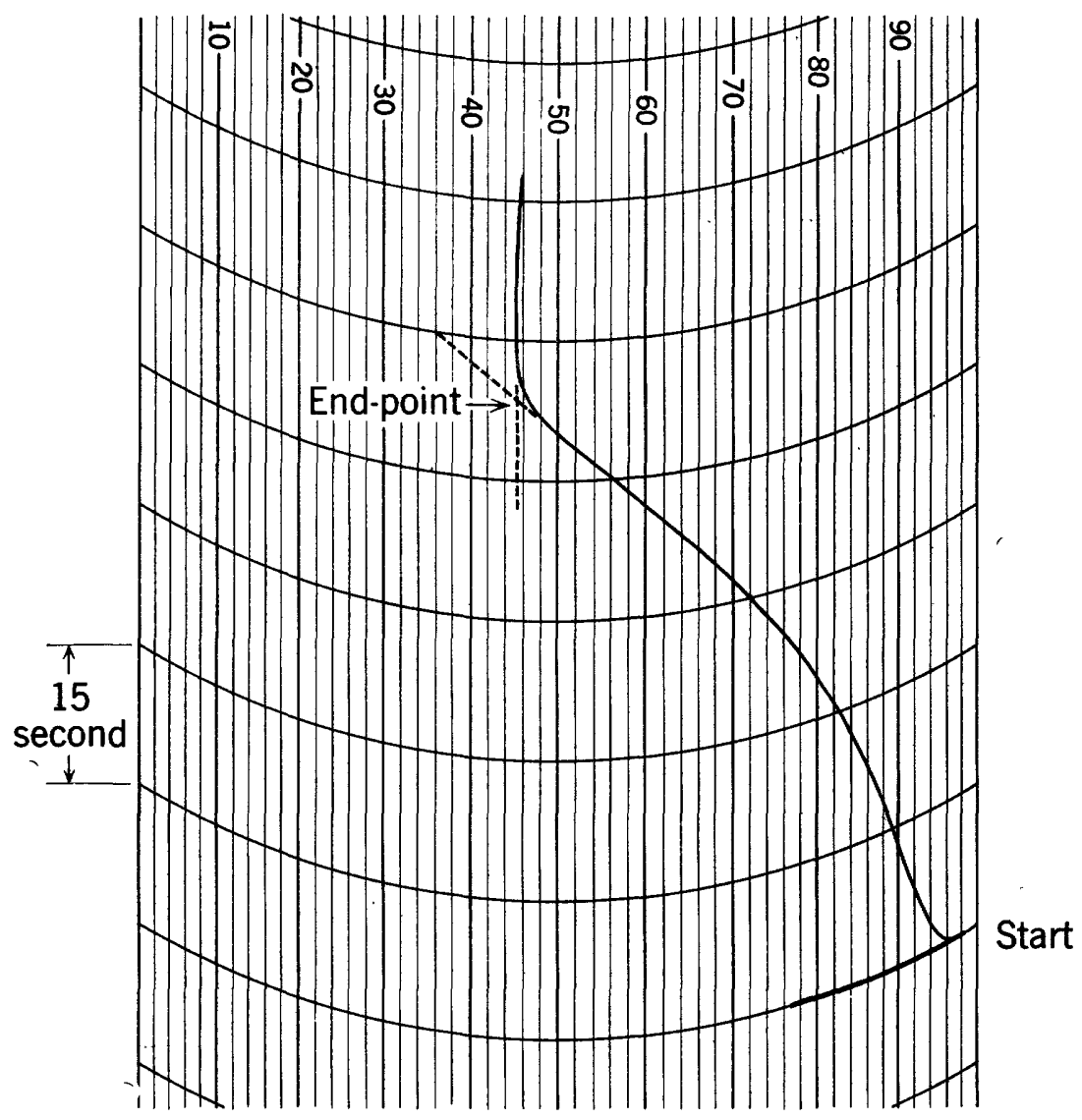

FISURE 11.-Titration curve. 


\section{CaLCULATIONS}

1. Obtain the blank correction:

$\left[(\right.$ Secs. for $1-\mathrm{ml}$ std. $\left.)-\left(\frac{\text { secs. for } 10-\mathrm{ml} \mathrm{std} \text {. }}{10}\right)\right] \times 1.1=$ blank correction.

Note: This is a better method of obtaining the blank correction than one in which the correction is obtained by direct titration of a reagent blank solution because the curve for a reagent blank solution, which usually eontains very little calcium, will be more poorly defined than one for a solution containing an appreciable amount of calcium.

2. Compute the factor:

3. Calculate percent $\mathrm{CaO}$ :

$\frac{3.05 \times 100}{\text { (Secs. for 10-ml std. }- \text { blank correction) } \times 20}=$ factor.

(Factor) $\times$ (secs. for sample - blank correction $)=$ percent $\mathrm{CaO}$.

\section{MgO}

Magnesia ( $\mathrm{MgO}$ ) is determined by titration with disodium ethylenediamine tetraacetate (Versene) using Eriochrome Black $\mathrm{T}$ as an indicator (Betz and Noll, 1950) after the rapid separation of the $\mathrm{R}_{2} \mathrm{O}_{3}$ group and precipitation of calcium as the tungstate.

$\mathrm{NH}_{4} \mathrm{OH}, 1+1$.

\section{REAGENTS}

Versene solution: The same solution as used for Determination of $\mathrm{CaO}$.

Buffer solution: Dissolve $66 \mathrm{~g}$ of $\mathrm{NH}_{4} \mathrm{Cl}$ in 1 liter of $1+1 \mathrm{NH}_{4} \mathrm{OH}$ and store in plastic bottle.

Sodium tungstate solution, 20 percent: prepare $500 \mathrm{ml}$.

Eriochrome Black $\mathrm{T}$ indicator solution, approximately 0.2 percent: Prepare 50 $\mathrm{ml}$. This solution should not be kept more than three days.

$\mathrm{CaCl}_{2}$ solution: Dissolve $500 \mathrm{mg}$ of $\mathrm{CaCO}_{3}$ in a few milliliters of $\mathrm{HCl}$ and dilute to $500 \mathrm{ml}$ with water.

$\mathrm{NH}_{4} \mathrm{Cl}$-methyl red solution: Add $10 \mathrm{ml}$ of 0.05 percent methyl red solution to 1 liter of 15 percent $\mathrm{NH}_{4} \mathrm{Cl}$.

Standard $\mathrm{MgO}$ solution: Transfer $0.752 \mathrm{~g}$ of magnesium ribbon or wire to a 250$\mathrm{ml}$ beaker. Add $10 \mathrm{ml}$ of $1+3 \mathrm{HCl}$, cover, and boil gently 1 to 2 minutes. Cool to room temperature and dilute to $200 \mathrm{ml}$ in a volumetric flask. Transfer $50 \mathrm{ml}$ to a 1-liter volumetric flask, dilute to volume, and mix. The solution contains the equivalent of $0.250 \mathrm{mg} \mathrm{MgO}$ per ml. Store solution in a plastic bottle.

\section{PROCEDURE}

1. Transfer $25 \mathrm{ml}$ of solution $\mathrm{B}$ (equivalent to $50 \mathrm{mg}$ of original sample) to $\mathrm{a}$ 250-ml volumetric flask.

2. Add about $200 \mathrm{ml}$ of water, $15 \mathrm{ml}$ of the $\mathrm{NH}_{4} \mathrm{Cl}$-methyl red solution and then add $1+1 \mathrm{NH}_{4} \mathrm{OH}$ dropwise, until the indicator turns yellow.

3. Dilute to volume, mix, and let stand $\mathbf{1 5}$ minutes.

4. Pour through a dry filter paper, or a dry funnel, catching $200 \mathrm{ml}$ of the filtrate in a dry $200-\mathrm{ml}$ volumetric flask. The $200 \mathrm{ml}$ of filtrate contains the equivalent of $40 \mathrm{mg}$ of original sample.

5. Transfer the contents of the flask to a $400-\mathrm{ml}$ beaker and rinse the flask with distilled water.

6. To two additional $400-\mathrm{ml}$ beakers add $1 \mathrm{ml}$ and $10 \mathrm{ml}$ of the standard $\mathrm{MgO}$ solution. Then add $200 \mathrm{ml}$ of water to each. 
7. To each beaker add $5 \mathrm{ml}$ of the $\mathrm{CaCl}_{2}$ solution, $10 \mathrm{ml}$ of the buffer solution, and $10 \mathrm{ml}$ of the sodium tungstate solution.

8. Bring the solutions to a boil and allow to boil 2 minutes. Then cool them to room temperature in a water bath.

9. Decant the solutions into $400-\mathrm{ml}$ titration beakers without rinsing. The major portion of the precipitated calcium tungstate will adhere to the sides of the beaker. The amount of solution left on the walls is inconsequential and extensive transfer of the tungstate precipitate is undesirable because the resulting cloudy solution diminishes the quality of the titration. Transfer of small quantities of precipitate is of no consequence.

10. Add $5 \mathrm{ml}$ of the buffer solution, $1 \mathrm{ml}$ of the Eliochrome Black $\mathrm{T}$ indicator solution and fill the beakers to the mark with distilled water.

11. Put a magnetic stirrer in the beaker containing the solution prepared from the 1-ml standard, place it in the titrator, and check to see that only the orange filter is in front of the photocell. (If a spectrophotometer is used, set at $670 \mathrm{~m} \mu$.)

12. Adjust the light to maximum intensity and then reduce it slightly so that the last movement of the recorder pen is from right to left.

13. Throw the toggle switch permitting the electromagnetic hosecock to open and the recorder to start.

14. As the titration proceeds, the pen which is tracing out the curve moves to the left as the color changes (fig. 11). When sufficient Versene solution has flowed into the beaker to react completely with the magnesium, the pen will no longer move to the left but will trace a line parallel with the direction of the chart movement. Allow the chart to move about 1 inch past this point, turn all switches to "off" and remove the beaker.

15. The curve is used to obtain the end point of the titration as illustrated in figure 11. A ruled line is extended from the last portion of the curve (the flat portion) and another line is extended along the portion of the curve immediately in front of the sudden change of direction. The intersection of the ruled lines is the end point. The time, in seconds, required for the titration is measured from the starting line to the end point.

16. Repeat steps 11 through 15 for the solution prepared from the $10-\mathrm{ml}$ aliquot of the standard solution (step 10).

17. Repeat steps 11 through 15 for the solution prepared from the sample solution (step 10).

\section{CALCULATIONS}

1. Obtain the blank correction:

$$
\left.[\text { (Secs. for } 1-\mathrm{ml} \text { std. })-\left(\frac{\text { secs. for } 10-\mathrm{ml} \text { std. }}{10}\right)\right] \times 1.1=\text { blank correction. }
$$

Note: This is a better method of obtaining the blank correction than one in which the correction is obtained by direct titration of a reagent blank solution because the curve for a reagent blank solution, which usually contains very little magnesium, will be more poorly defined than one for a solution containing an appreciable amount of magnesium.

2. Compute the factor:

$$
\frac{2.5 \times 100}{(\text { Secs. for } 10-\mathrm{ml} \text { std. }- \text { blank correction) } \times 40}=\text { factor. }
$$

3. Calculate percent $\mathrm{MgO}$ :

(Factor) $\times($ secs. for sample-blank correction $)=$ percent $\mathrm{MgO}$. 


\section{$\mathrm{K}_{2} \mathrm{O}$ AND $\mathrm{Na}_{2} \mathrm{O}$}

Potassium oxide and sodium oxide are determined by a flame photometer method in which lithium is used as an internal standard (Brannock and Berthold, 1953). The use of an internal standard reduces the effects due to differences in concentration of dissolved salts and differences in viscosity between standard and sample solutions and also reduces deviations in readings brought about by changes in the character of the flame resulting from small variations in air and gas pressures.

Satisfactory results for the alkalies are obtained by comparing each sample solution with two standard solutions-one in which the concentration of the alkali being determined is higher than in the sample solution, and the other in which it is lower. The concentration interval of the standard solutions used is relatively small and as a result the relationship between concentration of $\mathrm{K}_{2} \mathrm{O}$ or $\mathrm{Na}_{2} \mathrm{O}$ in the standard and sample solutions is essentially linear.

\section{REAGENTS}

$\mathrm{KCl}, \mathrm{NaCl}, \mathrm{Li}_{2} \mathrm{SO}_{4} \cdot \mathrm{H}_{2} \mathrm{O}$, all A. C. S. grade.

Stock solution of $\mathrm{KCl}$ : Prepare 2 liters of solution in which the concentration of $\mathrm{K}_{2} \mathrm{O}$ is $0.5 \mathrm{mg}$ per $\mathrm{ml}$, using $1.584 \mathrm{~g}$ of dry $\mathrm{KCl}$ and distilled water. Store in a Pyrex or plastic bottle.

Stock solution of $\mathrm{NaCl}$ : Prepare 2 liters of solution in which the concentration of $\mathrm{Na}_{2} \mathrm{O}$ is $0.5 \mathrm{mg}$ per $\mathrm{ml}$, using $1.886 \mathrm{~g}$ of dry $\mathrm{NaCl}$ and distilled water. Store in a plastic bottle.

Stock solution of $\mathrm{Li}_{2} \mathrm{SO}_{4}$ : Prepare 10 liters of solution in which the concentration of lithium is $2,000 \mathrm{ppm}$, using $184.4 \mathrm{~g}$ of $\mathrm{Li}_{2} \mathrm{SO}_{4} \cdot \mathrm{H}_{2} \mathrm{O}$ and distilled water. Store the solution in a Pyrex bottle.

Standard $\mathrm{K}_{2} \mathrm{O}$ solutions: Prepare solutions so that the concentration of $\mathrm{K}_{2} \mathrm{O}$ and lithium will be the same as that in sample solutions prepared, as described below in step 3 of Procedure, for samples containing exactly 0.5, 1, 2, 4, 6, 8, and 10 percent $\mathrm{K}_{2} \mathrm{O}$, by diluting $5,10,20,40,60$, and $100 \mathrm{ml}$ of the stock solution of $\mathrm{KCl}$ and $50 \mathrm{ml}$ of the stock solution of $\mathrm{Li}_{2} \mathrm{SO}_{4}$ to 1 liter with distilled water.

Standard $\mathrm{Na}_{2} \mathrm{O}$ solutions: Prepare solutions so that the concentration of $\mathrm{Na}_{2} \mathrm{O}$ and lithium will be the same as that in sample solutions prepared, as described below in step 3 of Procedure, for samples containing exactly $0.5,1,2,4,6$, 8 , and 10 percent $\mathrm{K}_{2} \mathrm{O}$, by diluting $5,10,20,40,60$, and $100 \mathrm{ml}$ of the stock solution of $\mathrm{NaCl}$ and $50 \mathrm{ml}$ of the stock solution of $\mathrm{Li}_{2} \mathrm{SO}_{4}$ to 1 liter with water.

Internal standard solution: Prepare 2 liters of solution in which the concentration of lithium is $200 \mathrm{ppm}$, by diluting $200 \mathrm{ml}$ of the stock solution of $\mathrm{Li}_{2} \mathrm{SO}_{4}$ with distilled water.

\section{PROCEDURE}

1. Light the burner of the flame photometer and adjust the flame as described under Apparatus and instruments-Flame photometer.

2. Turn the electric switch on the panel of the flame photometer to the "on" position.

3. To $25 \mathrm{ml}$ of solution $B$ in a Pyrex beaker or bottle add $25 \mathrm{ml}$ of distilled water and $50 \mathrm{ml}$ of the internal standard solution, containing $200 \mathrm{ppm}$ lithium, and mix. (Reservoir-type automatic pipets can be used to advantage in the addition of the water and the internal standard solutions.) 
4. If the approximate concentration of potassium in the sample solution can be estimated, omit steps 4 through 7 and proceed with step 8 . If the approximate concentration of potassium in the sample solution cannot be estimated, pour 25 to $30 \mathrm{ml}$ of the standard $\mathrm{K}_{2} \mathrm{O}$ solution, in which the concentration of $\mathrm{K}_{2} \mathrm{O}$ is equivalent to that of a solution prepared from a sample containing 10 percent $\mathrm{K}_{2} \mathrm{O}$, into a $50-\mathrm{ml}$ beaker. Place the beaker containing the standard solution in position on the beaker stand so that the atomizer inlet tube is immersed in the solution. As the solution atomizes into the flame, set the element selector to the position of maximum response for potassium.

5. With the same solution (step 4) atomizing into the flame set the internal standard dial to approximately 95 and adjust the coarse and fine gain controls so that the meter reads 50. Remove the beaker containing the standard solution and with no solution atomizing set the meter to read 50 with the zero adjusting knob. Replace the beaker with the same standard solution and while the solution atomizes adjust the internal standard dial so that the meter reads exactly 50. Record the setting of the internal standard dial. Remove the beaker and wipe the outside of the liquid inlet tube of the atomizer with a clean lintless tissue.

6. Put 25 to $30 \mathrm{ml}$ of the sample solution (step 3) into a $50-\mathrm{ml}$ beaker and place in position so that it atomizes into the flame. Adjust the internal standard dial so that the meter reads exactly 50 . Remove the beaker, wipe the atomizer tube with a tissue, and record the setting of the internal standard dial.

7. Assume the recorded reading to be proportional to the concentrations of potassium in standard and sample solutions, and calculate the approximate concentration of potassium as $\mathrm{K}_{2} \mathrm{O}$.

8. Repeat step 5 using the standard solution with the nearest higher concentration to the estimated concentration of potassium in the sample solution.

9. Repeat step 6.

10. Repeat step 6 using the standard solution with the nearest lower potassium concentration to the estimated concentration of potassium in the sample solution.

11. With the same solution (step 10) atomizing, shift the position of the internal standard dial and then reset it so that the meter again reads 50. Record the setting of the internal standard dial, remove the beaker and solution and wipe the atomizer tube.

12. Repeat step 6.

13. Repeat step 6 using the higher standard instead of the sample solution.

14. $\mathrm{Na}_{2} \mathrm{O}$ is determined on a portion of the same sample solution which was used for the determination of $\mathrm{K}_{2} \mathrm{O}$ (step 4). The element selector is set to the position of maximum response for sodium and the $\mathrm{Na}_{2} \mathrm{O}$ is determined in the same way as $\mathrm{K}_{2} \mathrm{O}$.

\section{CALCULATIONS}

1. The two-point equation below is used to calculate the concentration of $\mathrm{K}_{2} \mathrm{O}$ and $\mathrm{Na}_{2} \mathrm{O}$ in the sample solution after averaging the readings obtained for each standard and the sample solution.

$$
x=\frac{y-y_{1}}{y_{2}-y_{1}}\left(x_{2}-x_{1}\right)+x_{1}
$$

$x=$ concentration of $\mathrm{K}_{2} \mathrm{O}$ in the sample solution

$y=$ dial reading for the sample solution

$x_{1}=$ concentration of $\mathrm{K}_{2} \mathrm{O}$ in the lower standard solution

$y_{1}=$ dial reading for the lower standard solution

$x_{2}=$ concentration of $\mathrm{K}_{2} \mathrm{O}$ in the higher standard solution

$y_{2}=$ dial reading for the higher standard solution 
FeO

Ferrous iron is determined by the conventional titrimetric method using standard dichromate solution with diphenylamine sulfonic acid as the indicator (Sarver, 1927). When decomposition is carried out on batches of about eight samples simultaneously the time consumption per sample is small.

\section{REAGENTS}

$\mathrm{H}_{2} \mathrm{SO}_{4}, 48$ percent $\mathrm{HF}, \mathrm{K}_{2} \mathrm{Cr}_{2} \mathrm{O}_{7}$, all A. C. S. grade.

$\mathrm{H}_{2} \mathrm{SO}_{4}, 1+3$.

Diphenylamine sulfonate indicator: Dissolve $0.2 \mathrm{~g}$ of sodium diphenylamine sulfonate in 1 liter of water. Add 1 liter of 85 percent $\mathrm{H}_{3} \mathrm{PO}_{4}$ and mix well. Standard dichromate solution: Weigh $2.728 \mathrm{~g}$ of dry National Bureau of Standards potassium dichromate or other pure dry potassium dichromate and dilute to 2 liters in a volumetric flask. The solution contains the equivalent of $2.000 \mathrm{mg} \mathrm{FeO}$ per $\mathrm{ml}$.

\section{PROCEDURE}

1. Weigh $0.500 \mathrm{~g}$ of sample and place in platinum crucible of approximately $100-\mathrm{ml}$ volume.

2. Add $20 \mathrm{ml}$ of $1+3 \mathrm{H}_{2} \mathrm{SO}_{4}$ to the crucible, cover, and carefully bring to a boil over a gas burner or an electric heater.

3. Add about $10 \mathrm{ml}$ of $\mathrm{HF}$. Cover and again bring to a boil. Boil gently for 15 minutes.

4. While the solution in the crucible is boiling, add $400 \mathrm{ml}$ of water and approximately $10 \mathrm{~g}$ of boric acid to an 800-ml beaker. Stir the liquid in the beaker to aid in solution of the boric acid.

5. After the solution in the crucible has boiled for 15 minutes, remove the crucible from the heat with tongs, hold the cover on the crucible with a stirring rod, and immediately immerse the covered crucible and contents in the boric acid solution. The crucible should be kept covered after immersion, until just before the titration.

6. Add $10 \mathrm{ml}$ of the indicator solution and titrate the solution with standard dichromate solution to a purple end point which persists for 20 to 30 seconds.

\section{Calculations}

1. Compute percent $\mathrm{FeO}$ in the sample:

$$
\frac{\text { Dichromate }(\mathrm{ml}) \times 2.000}{500} \times 100=\text { percent } \mathrm{FeO} \text {. }
$$

Dichromate $(\mathrm{ml}) \times 0.4=$ percent $\mathrm{FeO}$.

\section{$\mathbf{H}_{2} \mathrm{O}$}

Water is determined by a modification of the Penfield method (Shapiro and Brannock, 1955b). The modified procedure is simpler and less time consuming than the conventional method.

\section{REAGENTS}

Sodium tungstate, anhydrous powder: Fuse several hundred grams of reagent $\mathrm{Na}_{2} \mathrm{WO}_{4} \cdot 2 \mathrm{H}_{2} \mathrm{O}$. Allow to cool, grind to a fine powder, and store in a jar with a tight-sealing cap. 


\section{PROCEDURE}

1. Transfer $1.000 \mathrm{~g}$ of sample powder to a dry $18 \mathrm{~mm}$ by $150 \mathrm{~mm}$ Pyrex test tube by means of a funnel. (For samples containing appreciable amounts of sulfur, mix $3 \mathrm{~g}$ of anhydrous sodium tungstate with the sample powder before placing into the tube.)

2. Cover the fingers of the hand which is easier to use in manipulation with finger stalls or a rubber glove. Roll a piece of 2 in. by 2 in. filter paper into a cylinder, slip it into an $18 \mathrm{~mm}$ by $65 \mathrm{~mm}$ tube, stopper the tube with a solid stopper and weigh. (To avoid absorption of moisture from the fingers, the paper should be handled only with covered fingers.)

3. Quickly transfer the paper eylinder from the weighing tube to the upper part of the $18 \mathrm{~mm}$ by $150 \mathrm{~mm}$ test tube which contains the sample powder and stopper with a one-holed stopper.

4. Place a 2 in. by 3 in. piece of wet paper around the outside of the upper portion of the ignition tube to cool the tube.

5. Place the tube in a horizontal position in a holder at a height that will allow the tube to get maximum heat from a Fisher burner (fig. 9).

6. Heat the closed end of the tube, gently at first, then at full heat of the burner for 5 minutes. Finally play the flame along the tube below the filter paper for 1 to 2 seconds to drive the water into the upper part of the tube. Allow to cool for at least 1 minute.

7. Remove the stopper and with the aid of a narrow spatula quickly wipe the walls of the tube surrounding the paper by gently pressing and rotating the filter paper cylinder one full rotation. With the fingers covered, quickly transfer the paper from the test tube to the weighing tube and replace the stopper in the weighing tube.

8. Weigh the tube containing the filter paper plus the absorbed water.

\section{CALCULATIONS}

1. Subtract the weight obtained in step 2 from the weight obtained in step 8 to obtain the weight of absorbed water.

2. A small part of the expelled water is not condensed and caught by the filter paper strip. A simple rule, which has been derived empirically, is used to get the value for total water in the sample from the value for water absorbed. If the amount of absorbed water is $20 \mathrm{mg}$ or less, increase the value by 10 percent. If the amount of absorbed water is over $20 \mathrm{mg}$, add $2 \mathrm{mg}$ to the value obtained.

3. Calculate percent water:

$\frac{\text { (Absorbed water, } \mathrm{mg}+\text { correction, } \mathrm{mg} \text { ) }}{10}=$ percent $\mathrm{H}_{2} \mathrm{O}$.

$\mathrm{CO}_{2}$

Carbon dioxide is determined by measuring the volume of gas evolved when powdered sample is heated with acid in a simple tube designed for the purpose (Shapiro and Brannock, 1955a). The carbonate tube is described under Apparatus and instruments and is shown in figure 10. In the method described below for Calibration of the carbonate tube, National Bureau of Standards standard sample 79 (fluorspar), which contains 0.97 percent $\mathrm{CO}_{2}$, is used. Any other material containing about 1 percent $\mathrm{CO}_{2}$ for which an accurate value is known can be used if the standard sample is not available. 


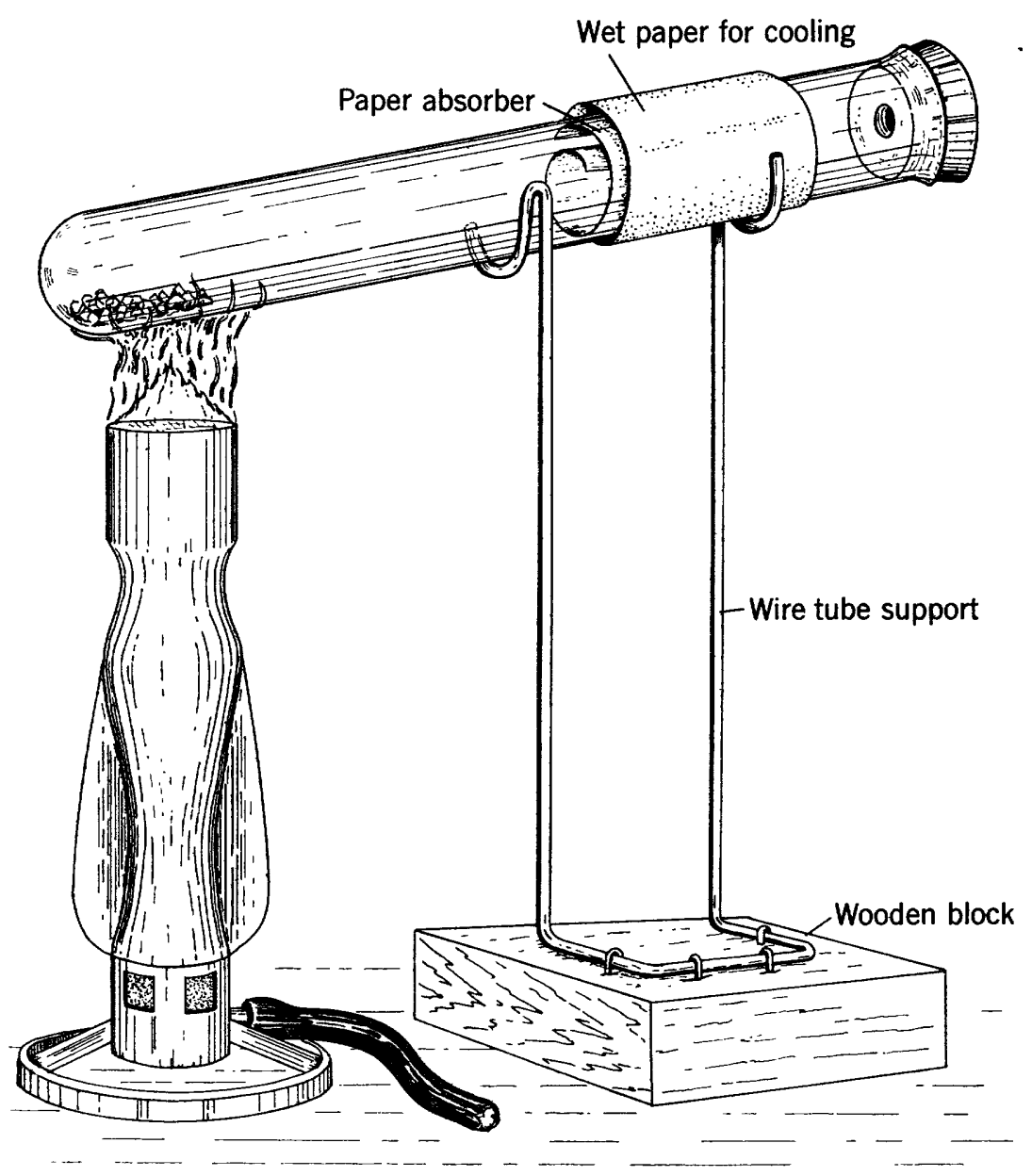

FInURE 12.-Water tube being heated on a support.

$\mathrm{HCl}, 1+1$.

REAGENTS

$\mathrm{HgCl}_{2}, 3$ percent: Prepare $100 \mathrm{ml}$. This solution is used to prevent the evolution of hydrogen which would otherwise occur as the result of the reaction between hydrochloric acid and "tramp iron" which may have been introduced as a contaminant by the sample-grinding apparatus.

Motor oil, S. A. E. no. 10. Addition of a small amount of antifoaming agent is desirable, although not essential.

\section{CALTBRATION OF THE CARBONATE TUBE}

1. Weigh $1.03 \mathrm{~g}$ of National Bureau of Standards standard sample no. 79 and transfer it by means of a dry funnel to the bottom of the carbonate tube.

2. Add $2 \mathrm{ml}$ of the $\mathrm{HgCl}_{2}$ solution and tap the tube to free entrapped air bubbles.

3. Add oil to the oil level mark.

4. Tilt the tube to allow all the air to escape from the side arm. Then return the tube to a position such that the main part of the tube is vertical. 
5. Add $2 \mathrm{ml}$ of $1+1 \mathrm{HCl}$ and tilt the tube so that the side arm is vertical to allow any $\mathrm{CO}_{2}$ produced to enter the side arm.

6. Heat the aqueous phase in one of two ways, either with a small gas flame or by means of an electrical heater so that it boils gently for 2 to $2 \frac{1}{2}$ minutes.

7. Allow cool tap water to flow down the outside of the side arm for 5 seconds. Remove from the stream of tap water and after 30 seconds mark the position of the meniscus on the side arm. This is the 1 percent mark.

8. Repeat steps 1 through 7 using $0,0.206,0.412,1.54,1.85$ and $2.06 \mathrm{~g}$ of the standard sample to obtain the calibration marks for $0,0.2,0.4,1.5,1.8$, and 2.0 percent $\mathrm{CO}_{2}$, respectively.

9. The tube can now be marked off by interpolation to give marks for each 0.1 percent $\mathrm{CO}_{2}$.

\section{PROCEDURE}

1. Transfer $1.000 \mathrm{~g}$ of sample powder to the bottom of the carbonate tube by means of a dry funnel.

2. Proceed as described in steps 2 to 6 under Calibration of the carbonate tube.

3. Allow cool tap water to flow down the outside of the side arm for 5 seconds. Remove from the stream of tap water and after 30 seconds estimate the percent $\mathrm{CO}_{2}$ from the scale on the side arm.

\section{EXPERIMENTAL RESULTS}

The methods described have been tested by analyzing 12 synthetic samples, 2 clay samples, a granite sample, and a diabase sample.

The synthetic samples were prepared by mixing National Bureau of Standards standard samples of limestone, dolomite, iron ore, bauxite, flint clay, plastic clay, feldspar, silica brick, and phosphate rock. These mixtures were prepared to include constituents which might be expected to be found in typical silicate rocks in appropriate concentration ranges. In several of the samples the concentration of $\mathrm{CO}_{2}$ was much higher than is found in typical silicate rocks. The concentration ranges are shown in table 2.

Table 3 shows the results obtained by two rapid analyses, made at widely different times, of the National Bureau of Standards mixture samples, compared with values computed from the analyses reported for the original samples by the Bureau of Standards.

The carbon dioxide concentrations in typical silicate rocks usually do not exceed several percent. The precision of the rapid procedure for $\mathrm{CO}_{2}$, which was designed for typical silicate rocks, falls off appreciably for samples containing abnormally high concentrations of this constituent. Better results can be obtained for samples in which $\mathrm{CO}_{2}$ exceeds 10 percent by calculations based on ignition loss determinations.

Table 4 shows the results obtained by two rapid analyses also made at widely different times of two clay samples, National Bureau of Standards standard samples 97 (flint clay) and 98 (plastic clay).

The National Bureau of Standards certificates do not supply information on some of the constituents for which data are shown for 
rapid analyses. In these cases the results for the rapid analyses are shown to indicate precision only.

A comparison of results obtained by rapid and conventional analysis for two rock samples that were used in an extensive collaborative study of precision and accuracy of silicate rock analysis (Fairbairn and otbers, 1951 ) is shown in table 5.

The averages of the values for double runs shown in tables 3,4 , and 5 are comparable to results obtainable by conventional means as demonstrated in Geological Survey Bulletin 980 (Fairbairn and others, 1951). The indicated accuracy for single runs would be satisfactory for many purposes where great saving in time and cost is important.

\section{REFERENCES CITED}

Bandemer, Selma L., and Schaible, P. J., 1944, Determination of iron: Indus. and Eng. Chemistry, Anal. Ed., v. 16, p. 317-319.

Barredo, J. M. G., and Taylor, J. K., 1947, Automatic recording of titrations: Electrochem. Soc. Trans., v. 92, p. 437-440.

Betz, J. B., and Noll, C. A., 1950, Total-hardness determination by direct colorimetric titration: Am. Water Works Assoc. Jour., v. 42, p. 49-56.

Brannock, W. W., and Berthold, Sarah M., 1953, The determination of sodium and potassium in silicate rocks by flame photometer: U. S. Geol. Survey Bull. 992, pt. 1, p. 1-14.

Bunting, W. E., 1944, The determination of soluble silica in very low concentration: Indus. and Eng. Chemistry, Anal. Ed., v. 16, p. 612-615.

Fairbairn, H. W., and others, 1951, A cooperative investigation of precision and accuracy in chemical, spectrochemical and modal analysis of silicate rocks: U. S. Geol. Survey Bull. 980.

Hillebrand, W. F., 1900, Some principles and methods of rock analysis: U. S. Geol. Survey Bull. 176.

Kitson, R. E., and Mellon, M. G., 1944, Colorimetric determinations of phosphorus as molybdivanadophosphoric acid: Indus. and Eng. Chemistry, Anal. Ed., v. 16, p. 379-383.

Parker, C. A., and Goddard, A. P., 1950, The reaction of aluminum ions with alizarin-3-sulphonate, with particular reference to the effect of calcium ions: Anal. Chem. Acta., v. 4, p. 517-524.

Sarver, L. A., 1927, The determination of ferrous iron in silicates: Am. Chem. Soc. Jour., v. 49, p. 1472-1477.

Shapiro, Leonard, and Brannock, W. W., 1952, Rapid analysis of silicate rocks: U. S. Geol. Survey Circ. 165.

1955a, Rapid determination of $\mathrm{CO}_{2}$ in silicate rocks: Anal. Chemistry, v. 27, p. $1796-97$.

$1955 \mathrm{~b}$, Rapid determination of water in silicate rocks: Anal. Chemistry, v. 27 , p. $560-564$.

Willard, H. H., and Greathouse, L. H., 1917, The colorimetric determination of manganese by oxidation with periodate: Am. Chem. Soc. Jour., v. 39, p. 2366-2377.

Yoe, J. H., and Armstrong, A. R., 1947, Colorimetric determination of titanium with disodium-1, 2-dihydroxbenzene-3, 5-disulfonate: Anal. Chemistry, v. 19 , p. 100-102. 
TABLE 1.-Conversion of percent transmission $(T)$ to absorbance $(A)$.

\begin{tabular}{|c|c|c|c|c|c|c|c|}
\hline $\mathrm{T}$ & A & $\mathrm{T}$ & A & $\mathrm{T}$ & A & $\mathrm{T}$ & $\mathbf{A}$ \\
\hline 30. 0 & 0.523 & 50. 0 & 0. 301 & 70.0 & 0.155 & 90.0 & 0. 046 \\
\hline 30. 5 & .516 & 50. 5 & .297 & 70.5 & .152 & 90.5 & .043 \\
\hline 31.0 & .509 & 51.0 & .292 & 71. 0 & .149 & 91.0 & .041 \\
\hline 31.5 & .502 & 51. 5 & .288 & 71.5 & .146 & 91.5 & .039 \\
\hline 32. 0 & .495 & 52. 0 & .284 & 72.0 & .143 & 92.0 & .036 \\
\hline 32.5 & .488 & 52.5 & .280 & 72.5 & .140 & 92.5 & .034 \\
\hline 33. 0 & .482 & 53. 0 & .276 & 73.0 & .137 & 93. 0 & .032 \\
\hline 33. 5 & .475 & 53.5 & .272 & 73. 5 & .134 & 93. 5 & .029 \\
\hline 34.0 & .469 & 54.0 & .268 & 74. 0 & .131 & 94.0 & .027 \\
\hline 34.5 & .462 & 54. 5 & .264 & 74.5 & .128 & 94. 5 & .025 \\
\hline 35.0 & .456 & 55. 0 & .260 & 75.0 & .125 & 95.0 & .022 \\
\hline 35.5 & .450 & 55.5 & .256 & 75.5 & .122 & 95.5 & .020 \\
\hline 36. 0 & .444 & 56.0 & .252 & 76. 0 & .119 & 96.0 & .018 \\
\hline 36.5 & .438 & 56. 5 & .248 & 76. 5 & .116 & 96.5 & .016 \\
\hline 37. 0 & . 432 & 57. 0 & .244 & 77. 0 & .114 & 97.0 & .013 \\
\hline 37.5 & .426 & 57. 5 & .240 & 77.5 & .111 & 97.5 & .011 \\
\hline 38.0 & .420 & 58. 0 & .237 & 78.0 & .108 & 98.0 & .009 \\
\hline 38. 5 & .415 & 58. 5 & .233 & 78.5 & .105 & 98.5 & .007 \\
\hline 39.0 & 409 & 59.0 & .229 & 79. 0 & .102 & 99. 0 & .004 \\
\hline 39. 5 & .403 & 59. 5 & .226 & 79. 5 & .100 & 99. 5 & .002 \\
\hline 40.0 & .398 & 60.0 & .222 & 80.0 & .097 & & \\
\hline 40.5 & .393 & 60.5 & .218 & 80.5 & .094 & & \\
\hline 41. 0 & .387 & 61.0 & .215 & 81.0 & .092 & & \\
\hline 41. 5 & 382 & 61.5 & .211 & 81. 5 & .089 & & \\
\hline 42. 0 & .377 & 62.0 & .208 & 82. 0 & .086 & & \\
\hline 42.5 & .372 & 62.5 & .204 & 82.5 & .084 & & \\
\hline 43. 0 & .367 & 63.0 & .201 & 83.0 & .081 & & \\
\hline 43. 5 & .362 & 63.5 & .197 & 83.5 & .078 & & \\
\hline 44. 0 & .357 & 64. 0 & .194 & 84.0 & .076 & & \\
\hline 44. 5 & .352 & 64.5 & .190 & 84.5 & .073 & & \\
\hline 45. 0 & .347 & 65.0 & .187 & 85. 0 & .071 & & \\
\hline 45. 5 & .342 & 65.5 & .184 & 85.5 & .068 & & \\
\hline 46. 0 & .337 & 66. 0 & .180 & 86. 0 & .066 & & \\
\hline 46. 5 & .333 & 66. 5 & .177 & 86. 5 & .063 & . & \\
\hline 47. 0 & .328 & 67. 0 & .174 & 87.0 & .060 & & \\
\hline 47. 5 & .323 & 67. 5 & .171 & 87.5 & .058 & & \\
\hline 48. 0 & .319 & 68.0 & .168 & 88.0 & .056 & & \\
\hline 48. 5 & .314 & 68. 5 & .164 & 88.5 & .053 & & \\
\hline 49. 0 & .310 & 69. 0 & .161 & 89.0 & .051 & & \\
\hline 49. 5 & .305 & 69. 5 & .158 & 89.5 & .049 & & \\
\hline
\end{tabular}


TABLE 2.-Concentration ranges of the test samples.

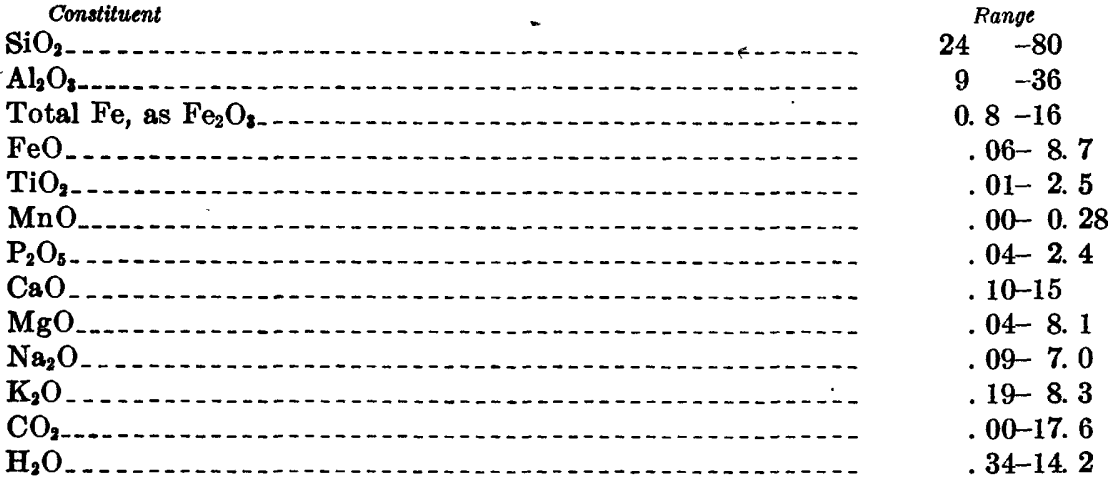

TABLE 3.-Results obtained for National Bureau of Standards (NBS) mixture samples ( $A$ to $L$ )

[Asterisk indicates determination based on ignition loss]

\begin{tabular}{|c|c|c|c|c|c|c|c|c|}
\hline & \multicolumn{4}{|c|}{ A } & \multicolumn{4}{|c|}{ B } \\
\hline & \multicolumn{3}{|c|}{ Rapid } & \multirow{2}{*}{ NBS } & \multicolumn{3}{|c|}{ Rapid } & \multirow{2}{*}{ NBS } \\
\hline & 1 & 2 & Av. & & 1 & 2 & Av. & \\
\hline $\mathrm{SiO}_{2-}$ & 24.6 & 24. 7 & 24. 6 & 24. 2 & 37.1 & 36.9 & 37.0 & 36. 8 \\
\hline $\mathrm{Al}_{2} \mathrm{O}_{3}$ & 24.8 & 24.0 & 24.4 & 24. 2 & 37.1 & 36. 3 & 36. 7 & 36. 3 \\
\hline $\mathrm{FeO}$ & .05 & .07 & .06 & $\ldots-\ldots$ & .06 & 2. 8 & 2. 8 & $\ldots$ \\
\hline $\mathrm{Fe}_{2} \mathrm{O}_{3} \ldots \ldots$ & 1. 9 & 1.8 & 1.8 & 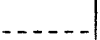 & 2.8 & 2.8 & 2. 8 & $\ldots$ \\
\hline $\mathrm{TiO}_{2}$ & .87 & .90 & .88 & .92 & 1. 3 & 1. 3 & 1. 3 & 1. 4 \\
\hline MnO.... & .00 & .00 & .00 & $\ldots \ldots$ & .00 & .01 & .00 & $\ldots$ \\
\hline $\mathrm{P}_{2} \mathrm{O}_{5}$ & .26 & .25 & .26 & 27 & .80 & .77 & .78 & .8 \\
\hline $\mathrm{CaO}$ & 10.4 & 10.4 & 10.4 & 10.5 & 1. 2 & 1. 2 & 1. 2 & 1. 3 \\
\hline $\mathrm{MgO}_{-}$ & 6. 9 & 7.0 & 7. 0 & 7.1 & .02 & .06 & .04 & .04 \\
\hline $\mathrm{Na}_{2} \mathrm{O}$ & .76 & .77 & .76 & .81 & 5. 4 & 5. 4 & 5. 4 & 5. 3 \\
\hline $\mathrm{K}_{2} \mathrm{O}$ & 4. 1 & 4. 1 & 4.1 & 4. 2 & .19 & .21 & .20 & .20 \\
\hline $\mathrm{H}_{2} \mathrm{O}_{\ldots} \ldots$ & 9.5 & 9. 7 & 9. 6 & 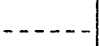 & 14. 3 & 14. 2 & 14.2 & \\
\hline $\mathrm{CO}_{2} \ldots \ldots$ & $\ldots$ & 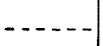 & *16. 1 & - & .16 & .18 & .17 & $-\cdots$ \\
\hline sum_ & & & 100.0 & & & & 99.8 & \\
\hline Total Fe as & & & & & & & & \\
\hline $\mathrm{Fe}_{2} \mathrm{O}_{3 \ldots} \ldots$ & 2.0 & 1.9 & 2.0 & 2.0 & 2. 9 & 2. 9 & 2.9 & 2. 9 \\
\hline
\end{tabular}


TABLE 3.-Results obtained for National Bureau of Standards (NBS) mixture samples $(A$ to $L)$-Continued

\begin{tabular}{|c|c|c|c|c|c|c|c|c|}
\hline & \multicolumn{4}{|c|}{$\mathrm{C}$} & \multicolumn{4}{|c|}{ D } \\
\hline & \multicolumn{3}{|c|}{ Rapid } & \multirow{2}{*}{ NBS } & \multicolumn{3}{|c|}{ Rapid } & \multirow{2}{*}{ NBS } \\
\hline & 1 & 2 & Av. & & 1 & 2 & Av. & \\
\hline $\mathrm{SiO}_{2-}$ & 35. 7 & 36.0 & 35.8 & 35. 4 & 71.3 & 70. 5 & 70. 9 & 71.0 \\
\hline $\mathrm{Al}_{2} \mathrm{O}_{3} \ldots$ & 26.0 & 25. 2 & 25.6 & 25.4 & 9.3 & 9.6 & 9.4 & 9.3 \\
\hline FeO & .16 & .14 & .15 & $\ldots$ & .14 & .14 & .14 & $\ldots$ \\
\hline $\mathrm{Fe}_{2} \mathrm{O}_{3}$ & 9.8 & 9.8 & 9.8 & ( & 11. 6 & 11. 7 & 11.6 & $-\ldots$ \\
\hline $\mathrm{TiO}_{2}$ & .78 & .84 & .81 & .84 & .02 & .05 & .04 & .06 \\
\hline MnO & .01 & 01 & .01 & $\ldots$ & .01 & .01 & .01 & $\ldots$ \\
\hline $\mathbf{P}_{2} \mathbf{O}_{5} \ldots \ldots$ & .41 & .40 & .40 & .39 & .29 & .28 & .28 & .25 \\
\hline $\mathrm{CaO}_{\ldots}$ & 3.9 & 3.8 & 3. 8 & 3. 9 & .70 & .84 & 77 & .78 \\
\hline MgO & 2. 3 & 2.4 & 2.4 & 2.5 & .46 & .50 & .48 & .50 \\
\hline $\mathrm{Na}_{2} \mathrm{O}$ & 1. 2 & 1. 1 & 1.2 & 1. 2 & 5.1 & 5.2 & 5. 2 & 5. 1 \\
\hline $\mathrm{K}_{2} \mathrm{O}_{\ldots} \ldots$ & 6.1 & 6.1 & 6.1 & 6.2 & .20 & .20 & .20 & .19 \\
\hline $\mathrm{H}_{2} \mathrm{O}$ & 8. 7 & 8. 6 & 8. 6 & $\ldots \ldots$ & .46 & .43 & .44 & $\ldots \ldots$ \\
\hline $\mathrm{CO}_{2 \ldots} \ldots$ & 4. 9 & 5. 1 & 5.0 & $\ldots$ & .53 & .55 & .54 & $\ldots$ \\
\hline \multirow{5}{*}{$\begin{array}{l}\text { Total Fe as } \\
\mathrm{Fe}_{2} \mathrm{O}_{3}\end{array}$} & & & 99.7 & & & $\ldots$ & 100.0 & - \\
\hline & 9.9 & 9.9 & 9.9 & 10. 1 & 11. 7 & 11.8 & 11.8 & 12.0 \\
\hline & \multicolumn{4}{|c|}{$\mathbf{E}$} & \multicolumn{4}{|c|}{$\mathbf{F}$} \\
\hline & \multicolumn{3}{|c|}{ Rapid } & \multirow{2}{*}{ NBS } & \multicolumn{3}{|c|}{ Rapid } & \multirow{2}{*}{ NBS } \\
\hline & 1 & 2 & Av. & & 1 & 2 & Av. & \\
\hline $\mathrm{SiO}_{2--}$ & 46. 8 & 46. 5 & 46. 6 & 46. 4 & 45. 2 & 45. 4 & 45. 3 & 45. 0 \\
\hline $\mathrm{Al}_{2} \mathrm{O}_{3} \ldots \ldots$ & 12. 7 & 13. 1 & 12. 9 & 12. 7 & 12. 1 & 12.3 & 12. 2 & 12.1 \\
\hline $\mathrm{FeO}$ & .25 & .23 & .24 & 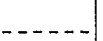 & .22 & .18 & .20 & $\ldots$ \\
\hline $\mathrm{Fe}_{2} \mathrm{O}_{3} \ldots$ & 15. 4 & 15. 9 & 15. 6 & - n & 7. 7 & 7. 6 & 7. 6 & $-\ldots$ \\
\hline $\mathrm{TiO}_{2} \ldots$ & .00 & .02 & 01 & .03 & .00 & .00 & .00 & 01 \\
\hline MnO $\ldots \ldots$ & .01 & .03 & .02 & $\ldots$ & .00 & .01 & .00 & $\ldots \ldots$ \\
\hline $\mathrm{P}_{2} \mathrm{O}_{5}$ & 2. 4 & 2. 3 & 2. 4 & 2. 4 & 2. 0 & 1. 9 & 2. 0 & 2. 0 \\
\hline $\mathrm{CaO}$ & 6.7 & 6. 9 & 6.8 & 6.8 & 8. 8 & 8. 8 & 8. 8 & 8. 8 \\
\hline $\mathrm{MgO}_{\ldots} \ldots \ldots$ & 2. 6 & 2. 8 & 2. 7 & 2. 7 & 4. 3 & 4. 5 & 4. 4 & 4. 4 \\
\hline $\mathrm{Na}_{2} \mathrm{O}_{\ldots} \ldots$ & 7. 0 & 6. 9 & 7. 0 & 7. 0 & 1.5 & 1. 5 & 1. 5 & 1. 6 \\
\hline $\mathrm{K}_{2} \mathrm{O}$ & .28 & .28 & .28 & .28 & 8. 2 & 8. 1 & 8. 2 & 8. 3 \\
\hline $\mathrm{H}_{2} \mathrm{O} \ldots \ldots$ & .74 & .78 & .76 & & .51 & .48 & .50 & $\ldots \ldots$ \\
\hline $\mathrm{CO}_{2} \ldots \ldots$ & 4. 4 & 4. 6 & 4. 5 & . & 8. 6 & 8. 6 & 8. 6 & 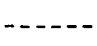 \\
\hline Sum_ & & & 99.8 & & & & 99.3 & $\ldots$ \\
\hline Total $\mathrm{Fe}$ as & & & & & & & & \\
\hline $\mathrm{Fe}_{2} \mathrm{O}_{3 \ldots} \ldots$ & 15. 6 & 16. 1 & 15. 8 & 15. 8 & 7. 9 & 7. 8 & 7.8 & 8. 0 \\
\hline
\end{tabular}


TABLE 3.-Results obtained for National Bureau of Standaards (NBS) mixture samples ( $A$ to $L)$-Continued

\begin{tabular}{|c|c|c|c|c|c|c|c|c|}
\hline & \multicolumn{4}{|c|}{ (1 } & \multicolumn{4}{|c|}{$\mathbf{H}$} \\
\hline & \multicolumn{3}{|c|}{ Rapid } & \multirow{2}{*}{ NBS } & \multicolumn{3}{|c|}{ Rapid } & \multirow{2}{*}{ NBS } \\
\hline & 1 & 2 & Av. & & 1 & 2 & Av. & \\
\hline $\mathrm{SiO}_{2-}$ & 37. 3 & 37. 6 & 37. 4 & 37. 6 & 45. 0 & 45.5 & 45. 2 & 45. 6 \\
\hline $\mathrm{Al}_{2} \mathrm{O}_{3 \ldots}$ & 10. 1 & 10. 2 & 10. 2 & 10. 1 & 12. 9 & 12.7 & 12. 8 & 12. 7 \\
\hline $\mathrm{FeO}_{\ldots} \ldots$ & .08 & .11 & .10 & $\ldots$ & .32 & .36 & .34 & - \\
\hline $\mathrm{Fe}_{2} \mathrm{O}_{3} \ldots$ & 3. 9 & 3. 9 & 3. 9 & $\ldots$ & 6.0 & 6. 1 & 6. 0 & $\ldots$ \\
\hline $\mathrm{TiO}_{2} \ldots \ldots$ & .00 & .01 & .00 & .01 & .04 & .07 & .06 & .06 \\
\hline $\mathrm{MnO}$ & .02 & .00 & .01 & $\ldots \ldots$ & .03 & .03 & .03 & $\ldots$ \\
\hline $\mathrm{P}_{2} \mathrm{O}_{5} \ldots$ & 1. 0 & 1. 0 & 1. 0 & 1.0 & 1.5 & 1. 5 & 1.5 & 1.5 \\
\hline $\mathrm{CaO}_{2}$ & 12. 6 & 13. 1 & 12. 8 & 12. 8 & 14. 5 & 14. 7 & 14. 6 & 14. 6 \\
\hline $\mathrm{MgO}$ & 8. 0 & 8. 2 & 8. 1 & 8. 1 & .94 & .86 & .90 & $=.91$ \\
\hline $\mathrm{Na}_{2} \mathrm{O}$ & 1. 3 & 1. 3 & 1. 3 & 1.4 & 6.5 & 6.7 & 6. 6 & 6.5 \\
\hline - - & 7. 0 & 6. 9 & 7. 0 & 7. 0 & .47 & .44 & .46 & .46 \\
\hline $\mathrm{H}_{2} \mathrm{O}_{\ldots}$ & .40 & .49 & .44 & $\ldots$ & .82 & .88 & .85 & $-\ldots$ \\
\hline $\mathrm{CO}_{2} \ldots \ldots$ & $\ldots-\cdots$ & $\ldots$ & *17. 6 & 1 & 9.2 & 9. 8 & 9.5 & $\ldots$ \\
\hline \multirow{6}{*}{$\begin{array}{r}\text { Total } \mathrm{Fe} \text { as } \\
\mathrm{Fe}_{2} \mathrm{O}_{3}\end{array}$} & & & 99.8 & & & $\ldots$ & 98.9 & - \\
\hline & & & & & & & & \\
\hline & 4. 0 & 4. 0 & 4. 0 & 4. 0 & 6.3 & 6. 4 & 6.4 & 6. 4 \\
\hline & \multicolumn{4}{|c|}{ I } & \multicolumn{4}{|c|}{$\mathbf{J}$} \\
\hline & \multicolumn{3}{|c|}{ Rapid } & \multirow{2}{*}{ NBS } & \multicolumn{3}{|c|}{ Rapid } & \multirow{2}{*}{ NBS } \\
\hline & 1 & 2 & Av. & & 1 & 2 & Av. & \\
\hline$\ldots$ & 79. 1 & 78.5 & 78. 8 & 79. 1 & 75.9 & 76.7 & 76. 3 & 76.5 \\
\hline $\mathrm{Al}_{2} \mathrm{O}_{3} \ldots \ldots$ & 12. 8 & 12. 6 & 12. 7 & 12. 9 & 13. 7 & 13. 6 & 13. 6 & 13. 8 \\
\hline $\mathrm{FeO}$ & .38 & .35 & .36 & $\ldots \ldots$ & .44 & .40 & .42 & $\ldots$ \\
\hline $\mathrm{Fe}_{2} \mathrm{O}_{3} \ldots$ & .82 & .62 & .72 & - & 1. 0 & 1. 0 & 1. 0 & $\ldots$ \\
\hline $\mathrm{TiO}_{2}$ & .74 & .74 & .74 & .76 & .78 & .80 & .79 & 80 \\
\hline $\mathrm{MnO}$ & .00 & .00 & .00 & $\ldots$ & .00 & .01 & .00 & $\ldots$ \\
\hline $\mathrm{P}_{2} \mathrm{O}_{5} \ldots$ & .07 & .05 & .06 & .04 & .07 & .09 & .08 & .05 \\
\hline $\mathrm{CaO}_{\ldots}$ & .16 & .12 & .14 & .12 & 1. 3 & 1. 3 & 1. 3 & 1. 2 \\
\hline $\mathrm{MgO}$ & .36 & .43 & .40 & .37 & .42 & .51 & .46 & .46 \\
\hline $\mathrm{Na}_{2} \mathrm{O}$ & .20 & .22 & .21 & .14 & .17 & .17 & .17 & .17 \\
\hline $\mathrm{K}_{2} \mathrm{O} \ldots \ldots$ & 1. 6 & 1. 6 & 1. 6 & 1. 6 & 1. 6 & 1.6 & 1. 6 & 1. 7 \\
\hline $\mathrm{H}_{2} \mathrm{O} \ldots \ldots$ & 4. 0 & 3. 9 & 4. 0 & $\ldots$ & 4. 1 & 4. 1 & 4. 1 . & $\ldots-$ \\
\hline $\mathrm{CO}_{2} \ldots \ldots$ & .00 & .00 & .00 & $\ldots$ & .00 & .00 & & $\ldots$ \\
\hline Sum_ & & & 99. 7 & & & $\ldots$ & 99.7 & $\ldots$ \\
\hline Total $\mathrm{Fe}$ as & & & & & & & & \\
\hline $\mathrm{Fe}_{2} \mathrm{O}_{3 \ldots} \ldots$ & 1. 2 & 1. 0 & 1. 1 & 1. 1 & 1. 4 & 1. 4 & 1. 4 & 1. 4 \\
\hline
\end{tabular}


TABLE 3.-Results obtained for National Bureau of Standards (NBS) mixture samples $(A$ to $L)$-Continued

\begin{tabular}{|c|c|c|c|c|c|c|c|c|}
\hline & \multicolumn{4}{|c|}{$\mathbf{K}$} & \multicolumn{4}{|c|}{$\mathbf{L}$} \\
\hline & \multicolumn{3}{|c|}{ Rapid } & \multirow{2}{*}{ NBS } & \multicolumn{3}{|c|}{ Rapid } & \multirow{2}{*}{ NBS } \\
\hline & 1 & 2 & Av. & & 1 & 2 & Av. & \\
\hline $\mathrm{SiO}_{2--}$ & 67.7 & 68.0 & 67.8 & 68. 1 & 63.4 & 64.2 & 63.8 & 63.7 \\
\hline $\mathrm{Al}_{2} \mathrm{O}_{3}$ & 19. 4 & 19. 4 & 19. 4 & 20.3 & 21. 7 & 21. 7 & 21. 7 & 22. 2 \\
\hline FeO & .15 & .13 & .14 & $\ldots \ldots$ & .11 & .13 & .12 & $\ldots$ \\
\hline $\mathrm{Fe}_{2} \mathrm{O}_{3} \ldots$ & .75 & .60 & .66 & $-\ldots$ & 1.0 & 1.0 & 1. 0 & $\ldots$ \\
\hline $\mathrm{TiO}_{2} \ldots$ & 1. 3 & 1. 3 & 1. 3 & 1. 3 & .70 & .73 & .72 & .72 \\
\hline $\mathrm{MnO}_{\ldots} \ldots$ & .40 & .44 & .42 & .42 & .26 & .26 & .26 & .28 \\
\hline $\mathrm{P}_{2} \mathrm{O}_{5} \ldots \ldots$ & .06 & .07 & .06 & .05 & .13 & .13 & .13 & .11 \\
\hline $\mathrm{CaO}$ & 1.2 & 1.1 & 1.2 & 1.2 & .32 & .30 & .31 & .28 \\
\hline $\mathrm{MgO}$ & .20 & .27 & .24 & .23 & .36 & .28 & .32 & .38 \\
\hline $\mathrm{Na}_{2} \mathrm{O}$ & .03 & .06 & .04 & .09 & 5.3 & 5.5 & 5.4 & 5.5 \\
\hline $\mathrm{K}_{2} \mathrm{O} \ldots \ldots$ & .42 & .41 & .42 & .41 & 1. 7 & 1.8 & 1.8 & 1. 8 \\
\hline $\mathrm{H}_{2} \mathrm{O} \ldots \ldots$ & 6. 9 & 6. 9 & 6.9 & & 4. 2 & 4. 1 & 4. 2 & $\ldots$ \\
\hline $\mathrm{CO}_{2} \ldots$ & .00 & .00 & .00 & - & .00 & .00 & .00 & $\ldots$ \\
\hline Sum. & & & 98. 6 & & & & 99.8 & $\ldots$ \\
\hline Total $\mathrm{Fe}$ as & & & & & & & & \\
\hline $\mathrm{Fe}_{2} \mathrm{O}_{3} \ldots \ldots$ & .90 & .73 & .81 & .82 & 1. 1 & 1. 1 & 1. 1 & 1. 1 \\
\hline
\end{tabular}


TABLE 4.-Results obtained for two National Bureau of Standards standard clay samples ( 97 and 98$)$

\begin{tabular}{|c|c|c|c|c|c|c|c|c|}
\hline \multirow[b]{3}{*}{ i } & \multicolumn{4}{|c|}{97} & \multicolumn{4}{|c|}{98} \\
\hline & \multicolumn{3}{|c|}{ Rapid } & \multirow{2}{*}{ NBS } & \multicolumn{3}{|c|}{ Rapid } & \multirow{2}{*}{ NBS } \\
\hline & 1 & 2 & Av. & & 1 & 2 & Av. & \\
\hline $\mathrm{SiO}_{2-}$ & 43.0 & 43. 0 & 43.0 & 42.9 & 58.6 & 58.5 & 58.6 & 59.1 \\
\hline $\mathrm{Al}_{2} \mathrm{O}_{3 \ldots} \ldots$ & 38.4 & 38.2 & 38.3 & 38.8 & 25.5 & 24. 9 & 25. 2 & 25. 5 \\
\hline $\mathrm{FeO}$ & .52 & .51 & .52 & $\ldots$ & .58 & .60 & .59 & \\
\hline $\mathrm{Fe}_{2} \mathrm{O}_{3 \ldots}$ & .43 & .40 & .42 & 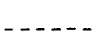 & 1.4 & 1.3 & 1.4 & \\
\hline $\mathrm{TiO}_{2 \ldots}$ & 2.4 & 2. 4 & 2. 4 & 2. 4 & 1. 4 & 1.4 & 1.4 & 1.4 \\
\hline $\mathrm{MnO}$ & .00 & .00 & .00 & $\ldots$ & .00 & .00 & .00 & $\ldots$ \\
\hline $\mathrm{P}_{2} \mathrm{O}_{6}$ & .12 & .10 & .11 & .08 & .13 & .11 & .12 & .08 \\
\hline $\mathrm{CaO}$ & .16 & .12 & .14 & .10 & .21 & .25 & .23 & .21 \\
\hline $\mathrm{MgO}$ & .22 & .26 & .24 & .26 & .68 & .71 & .70 & .72 \\
\hline $\mathrm{Na} \mathrm{a}_{2} \mathrm{O}$ & .18 & .10 & .14 & .12 & .32 & .31 & .32 & .28 \\
\hline $\mathrm{K}_{2} \mathrm{O}$ & .53 & .54 & .54 & .54 & 3. 1 & 3.1 & 3. 1 & 3.2 \\
\hline $\mathrm{H}_{2} \mathrm{O}_{\ldots} \ldots$ & 13. 3 & 13.0 & 13. 2 & & 7. 5 & 7.6 & 7. 6 & 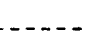 \\
\hline $\mathrm{CO}_{2 \ldots} \ldots \ldots$ & .00 & .00 & .00 & $\ldots$ & .00 & .00 & .00 & $\ldots$ \\
\hline Sum & & & 99.0 & & & & 99.2 & \\
\hline Total $\mathrm{Fe}$ as & & & & & & & & \\
\hline $\mathrm{Fe}_{2} \mathrm{O}_{3}$ & .95 & .91 & .93 & .98 & 2. 0 & 1.9 & 2. 0 & 2. 0 \\
\hline
\end{tabular}


TABLE 5.-Results obtained by rapid and conventional analysis of two carefully studied rock samples

[Results shown for conventional method are averages of results obtained by five analysts in another laboratory of the Geological Survey. The samples used are described by Fairbairn and others (1951).]

\begin{tabular}{|c|c|c|c|c|c|c|c|c|}
\hline & \multicolumn{4}{|c|}{ Granite (G-1) } & \multicolumn{4}{|c|}{ Diabase $(W-1)$} \\
\hline & \multicolumn{3}{|c|}{ Rapid } & \multirow{2}{*}{$\begin{array}{c}\text { Con- } \\
\text { ven- } \\
\text { tional }\end{array}$} & \multicolumn{3}{|c|}{ Rapid } & \multirow{2}{*}{$\begin{array}{l}\text { Con- } \\
\text { ven- } \\
\text { tional }\end{array}$} \\
\hline & 1 & 2 & Av. & & 1 & 2 & Av. & \\
\hline $\mathrm{SiO}_{2--}$ & 72.4 & 72.5 & 72.4 & 72.5 & 52.7 & 52.7 & 52.7 & 52.6 \\
\hline $\mathrm{Al}_{2} \mathrm{O}_{3 \ldots} \ldots \ldots$ & 14. 7 & 14.3 & 14. 5 & 14. 3 & 15.3 & 14.9 & 15. 1 & 15. 2 \\
\hline $\mathrm{FeO}$ & .97 & .94 & .96 & .95 & 8. 8 & 8.8 & 8. 8 & 8.7 \\
\hline $\mathrm{Fe}_{2} \mathrm{O}_{3} \ldots \ldots$ & .84 & .87 & .86 & .84 & 1.2 & 1. 4 & 1. 3 & 1. 4 \\
\hline $\mathrm{TiO}_{2} \ldots \ldots$ & .23 & .24 & .24 & .25 & 1.0 & 1. 1 & 1.0 & 1. 1 \\
\hline MnO & .02 & .02 & .02 & .03 & .18 & .20 & .19 & .16 \\
\hline $\mathrm{P}_{2} \mathrm{O}_{5}$ & .08 & .07 & .08 & .09 & .17 & .16 & .16 & .15 \\
\hline $\mathrm{CaO}$ & 1.3 & 1.4 & 1.4 & 1.3 & 10.8 & 10.6 & 10. 7 & 10.9 \\
\hline $\mathrm{MgO}$ & .34 & .28 & .31 & .36 & 6.5 & 6.7 & 6.6 & 6.6 \\
\hline $\mathrm{Na}_{2} \mathrm{O}$ & 3.3 & 3. 3 & 3. 3 & 3.3 & 2.2 & 2.1 & 2. 2 & 2. 1 \\
\hline $\mathrm{K}_{2} \mathrm{O}$ & 5. 4 & 5. 4 & 5. 4 & 5. 5 & .66 & .62 & .64 & .66 \\
\hline $\mathrm{H}_{2} \mathrm{O}$ & .30 & .32 & .31 & .34 & .52 & .56 & .54 & .59 \\
\hline $\mathrm{CO}_{2} \ldots$ & .10 & .12 & .11 & .07 & .07 & .05 & .06 & .05 \\
\hline Sum & & & 99.9 & & & & 100.0 & - \\
\hline Total $\mathrm{Fe}$ as & & & & & & & & \\
\hline $\mathrm{Fe}_{2} \mathrm{O}_{3} \ldots$ & 1.8 & 1. 8 & 1.8 & & 10.8 & 11.0 & 10.9 & $\ldots$ \\
\hline
\end{tabular}






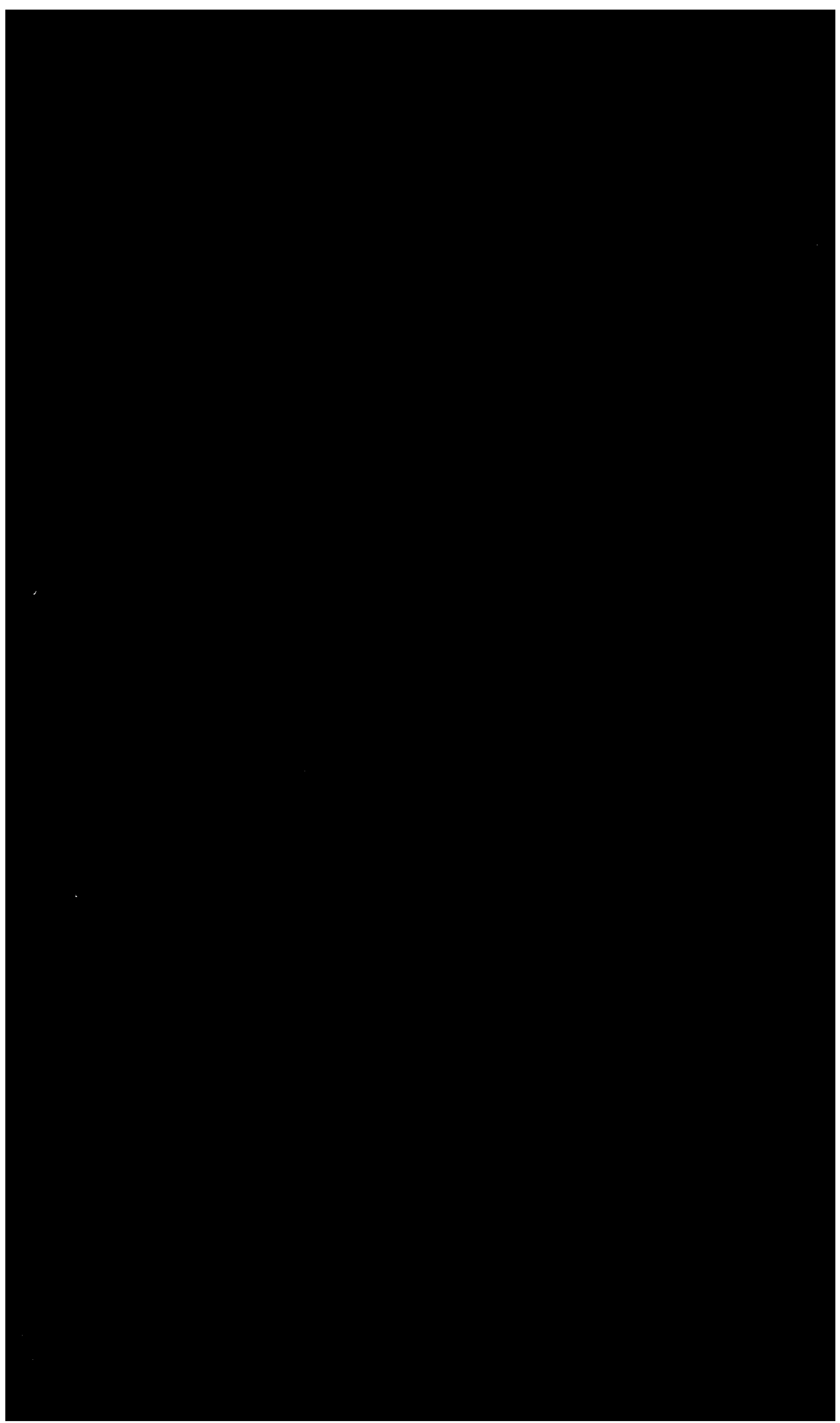




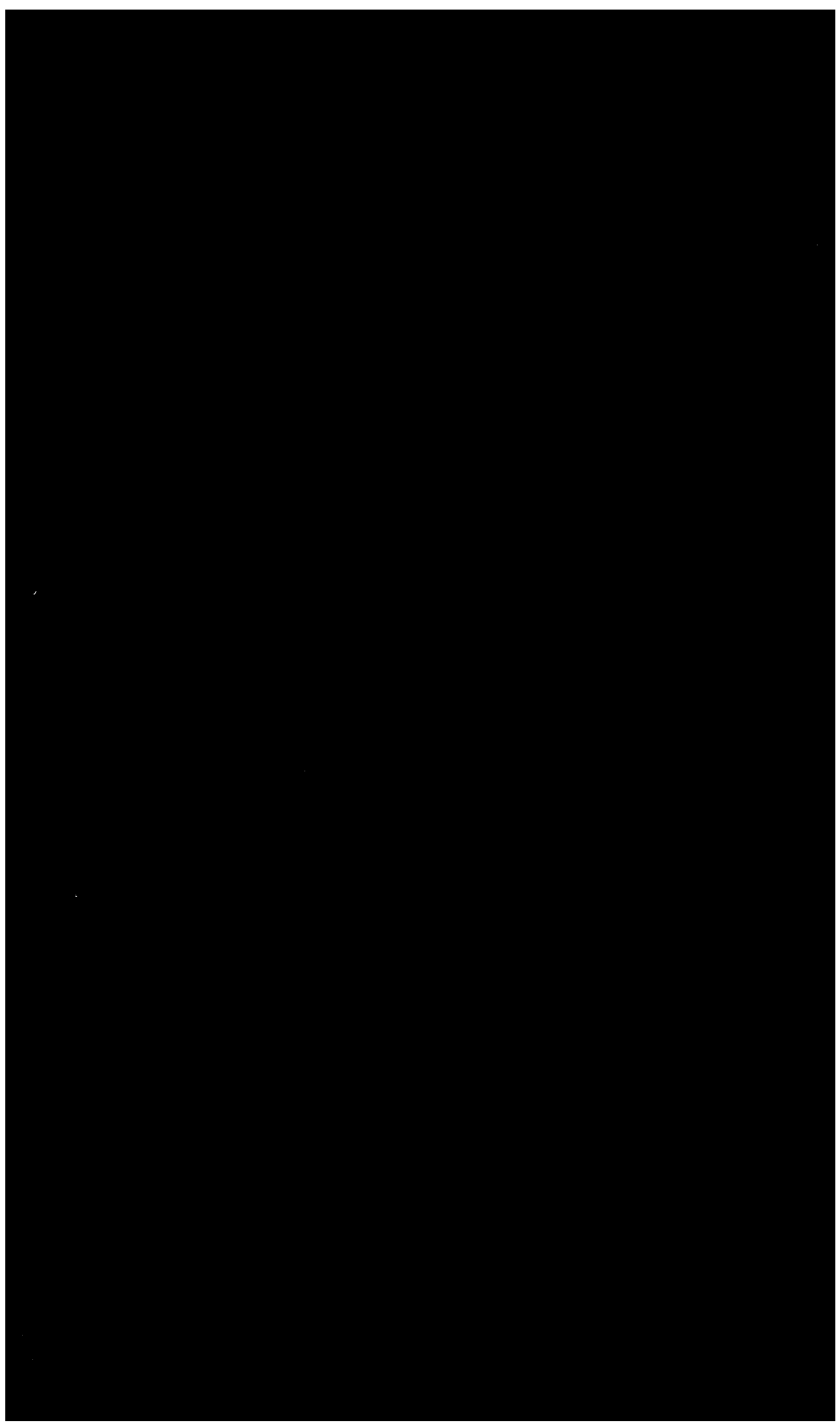

